\title{
Characterization of volatile organic compounds (VOCs) in Asian and north American pollution plumes during INTEX-B: identification of specific Chinese air mass tracers
}

\author{
B. Barletta ${ }^{1}$, S. Meinardi ${ }^{1}$, I. J. Simpson ${ }^{1}$, E. L. Atlas ${ }^{2}$, A. J. Beyersdorf ${ }^{3}$, A. K. Baker ${ }^{4}$, N. J. Blake ${ }^{1}$, M. Yang ${ }^{1}$, \\ J. R. Midyett ${ }^{1}$, B. J. Novak ${ }^{1}$, R. J. McKeachie ${ }^{1}$, H. E. Fuelberg ${ }^{5}$, G. W. Sachse ${ }^{3}$, M. A. Avery ${ }^{3}$, T. Campos $^{6}$, A. J. \\ Weinheimer $^{6}$, F. S. Rowland ${ }^{1}$, and D. R. Blake ${ }^{1}$ \\ ${ }^{1}$ University of California, Irvine, 531 Rowland Hall, Irvine 92697 CA, USA \\ ${ }^{2}$ University of Miami, RSMAS/MAC, 4600 Rickenbacker Causeway, Miami, 33149 FL, USA \\ ${ }^{3}$ NASA Langley Research Center, Hampton, 23681 VA, USA \\ ${ }^{4}$ Max Plank Institute, Atmospheric Chemistry Dept., Johannes-Joachim-Becherweg 27, 55128 Mainz, Germany \\ ${ }^{5}$ Florida State University, Department of Meteorology, Tallahassee Florida 32306-4520, USA \\ ${ }^{6}$ NCAR, 1850 Table Mesa Drive, Boulder, 80305 CO, USA
}

Received: 9 March 2009 - Published in Atmos. Chem. Phys. Discuss.: 24 March 2009

Revised: 16 June 2009 - Accepted: 17 June 2009 - Published: 30 July 2009

\begin{abstract}
We present results from the Intercontinental Chemical Transport Experiment - Phase B (INTEX-B) aircraft mission conducted in spring 2006. By analyzing the mixing ratios of volatile organic compounds (VOCs) measured during the second part of the field campaign, together with kinematic back trajectories, we were able to identify five plumes originating from China, four plumes from other Asian regions, and three plumes from the United States. To identify specific tracers for the different air masses we characterized their VOC composition and we compared their background levels with those obtained during the 2004 INTEX-A mission. The Chinese and other Asian air masses were significantly enhanced in carbonyl sulfide (OCS) and methyl chloride $\left(\mathrm{CH}_{3} \mathrm{Cl}\right)$, while all $\mathrm{CFC}$ replacement compounds were elevated in US plumes, particularly HFC-134a.

Although elevated mixing ratios of Halon-1211 were measured in some Chinese plume samples, several measurements at background levels were also observed. After analyzing the VOC distribution and correlations within the Chinese pollution plumes and applying principal component analysis (PCA), we suggest the use of a suite of species, rather than a single gas, as specific tracers of Chinese air masses (namely OCS, $\mathrm{CH}_{3} \mathrm{Cl}, 1$,2-dichloroethane, ethyl chloride, and Halon1211). In an era of constantly changing halocarbon usage patterns, this suite of gases best reflects new emission characteristics from China.
\end{abstract}

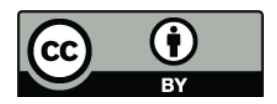

Correspondence to: B. Barletta (bbarlett@uci.edu)

\section{Introduction}

The Intercontinental Chemical Transport Experiment Phase B (INTEX-B) aircraft experiment was conducted in the spring of 2006. Its broad objective was to understand the behavior of trace gases and aerosols on transcontinental and intercontinental scales, and their impact on air quality and climate (an overview of the INTEX-B campaign can be found in Singh et al., 2009). The first part of INTEX-B was carried out from 4-31 March 2006 and focused on Mexico City pollution. In this paper we present results from the second part of INTEX-B (4 April-15 May 2006) which focused on the transport, transformation and evolution of Asian pollution to North America at the time of year when long-range transport of Asian pollution across the Pacific region is at a maximum (Jaffe et al., 2001; Stohl et al., 2002; Liu et al., 2003; Forster et al., 2004; Liang et al., 2004). The INTEX-B mission utilized the NASA DC- 8 and the NSF/NCAR C-130 research aircraft. Among many other measurements, whole air samples were collected on board the two aircraft and were analyzed for selected volatile organic compounds (VOCs). The importance and role of VOCs on the formation of tropospheric ozone is well known (Seinfeld, 1989; Atkinson, 2000; Heard and Pilling, 2003). Briefly, ozone is produced in the troposphere by the oxidation of VOCs in the presence of sunlight and nitrogen oxides $\left(\mathrm{NO}_{\mathrm{x}}=\mathrm{NO}+\mathrm{NO}_{2}\right)$. Ozone is a recognized greenhouse gas (e.g. Berntsen et al., 1997) and is unhealthful at enhanced concentrations (Bell et al., 2004). Many of the measured halogenated compounds presented 
here are regulated under the Montreal Protocol and its subsequent amendments because of their potential to deplete stratospheric ozone (WMO, 2003; UNEP, 2003).

Other NASA field campaigns and modeling studies have focused on Asian outflow. In particular, the spring 2001 Transport and Chemical Evolution over the Pacific (TRACEP) experiment characterized the VOC composition of Asian outflow (see Jacob et al., 2003 for an overview of the TRACE-P campaign). Several Chinese pollution plumes were encountered during TRACE-P and elevated VOC concentrations were measured over the Yellow Sea, the Formosa Strait, and downwind of Shanghai (Blake et al., 2003; Simpson et al., 2003). However, during TRACE-P most of the air samples were collected over the western Pacific Rim region, very close to the emission sources. The Intercontinental Chemical Transport Experiment - North America Phase A (INTEX-A) experiment in summer 2004 investigated the inflow and outflow of pollution over the North American continent during a period of inefficient transport over the Pacific region. The INTEX-A data were collected predominantly over the US, Eastern Pacific and Western Atlantic between latitudes of $27-52^{\circ} \mathrm{N}$ (Fig. 1a). The transport of Asian pollution across the Pacific is at a minimum in summer months because part of the Asian outflow is transported westward (Lelieveld et al., 2002; Liu et al., 2002, 2003) and because of longer trans-Pacific transport times in summer (6-10 days) versus spring (1-5 days; Liang et al., 2004; Holzer et al., 2005).

By contrast, the springtime INTEX-B experiment evaluated the impact of Asian outflow on North American when the strongest outflow occurs and the VOC load reaches its maximum. During INTEX-B the DC-8 and C-130 aircraft flew over the Eastern Pacific region, along the coast of North America, and over the United States (Fig. 1b). Here we describe the identification of specific pollution plumes that originated from Asia and their comparison to air masses of North American origin. In particular, since emissions from China have evolved during the past decade, a goal was to identify a specific sub-set of VOCs characteristic of Chinese pollution plumes that can be used as specific "tracers" for modern Chinese air masses.

\section{Experimental}

During the second deployment of INTEX-B a total of 2441 whole air samples (WAS) were collected on board the two aircraft (1594 from the DC-8 and 847 from the C-130) during 22 science flights. Samples were collected in 2-L electropolished stainless steel canisters equipped with a Swagelok metal bellows valve. Prior to shipping to the field the canisters were flushed with ultra-high purity (UHP) helium and subsequently evacuated to $10^{-2}$ Torr in our laboratory at the University of California, Irvine (UC-Irvine). Seventeen Torr of degassed ultrapure MilliQ water were added to the canisters in order to passivate the surface of the internal walls, so that the absorbance of selected compounds inside the canisters would be minimized. During the sampling the canisters were pressurized to $40 \mathrm{psi}$ using a metal double bellows pump. The filling time was approximately one minute. Canisters were filled at 1-3 min intervals during ascents and descents, and every 2-8 min during horizontal flight legs. A maximum of 168 canisters were filled for each flight on the DC- 8 and 72 aboard the C-130. Once filled, the canisters were shipped back to our UC-Irvine laboratory where - within 7 days of sample collection - they were analyzed for more than 75 gases including nonmethane hydrocarbons, halocarbons, alkyl nitrates and sulfur compounds.

A detailed description of the analytical system is described in Colman et al. (2001). Briefly, a sample amount of $2440 \pm 3 \mathrm{~cm}^{3}$ (STP) of the air was preconcentrated in a stainless steel loop filled with glass beads and submerged in liquid nitrogen. The sample was then heated to about $80^{\circ} \mathrm{C}$, injected, and split into six different column/detector combinations using UHP helium as the carrier gas. The first column detector combination was a DB- 1 column $(\mathrm{J} \& W ; 60 \mathrm{~m}$, $0.32 \mathrm{~mm}$ I.D., $1 \mu \mathrm{m}$ film thickness) output to a flame ionization detector (FID). The second was a DB-5 column (J\&W; $30 \mathrm{~m}, 0.25 \mathrm{~mm}$ I.D., $1 \mu \mathrm{m}$ film thickness) column connected in series to a RESTEK 1701 column ( $5 \mathrm{~m}, 0.25 \mathrm{~mm}$ I.D., $0.5 \mu \mathrm{m}$ film thickness) and output to an electron capture detector (ECD). The third was a RESTEK 1701 column (60 m, $0.25 \mathrm{~mm}$ I.D., $0.50 \mu \mathrm{m}$ film thickness) output to an ECD. The fourth combination was a PLOT column (J\&W GSAlumina; $30 \mathrm{~m}, 0.53 \mathrm{~mm}$ I.D.) connected in series to a DB1 column (J\&W; $5 \mathrm{~m}, 0.53 \mathrm{~mm}$ I.D., $1.5 \mu \mathrm{m}$ film thickness) and output to an FID. The fifth was a DB-5ms column (J\&W; $60 \mathrm{~m}, 0.25 \mathrm{~mm}$ I.D., $0.5 \mu \mathrm{m}$ film thickness) output to a nitrogen phosphorus detector (NPD). The final combination was a DB-5ms column (J\&W; $60 \mathrm{~m}, 0.25 \mathrm{~mm}$ I.D., $0.5 \mu \mathrm{m}$ film thickness) output to a quadrupole mass spectrometer detector (MSD, HP 5973). The MSD was set to operate in selected ion monitoring (SIM) mode with one ion chosen to quantify each compound in order to achieve the maximum selectivity and to avoid potential interferences. All of the gas chromatographs and detectors used for this project were manufactured by Hewlett Packard.

Our analytical accuracy ranges from 2 to $20 \%$, and the precision of the measurements vary by compound and by mixing ratio. For instance, the measurement precision is $1 \%$ or $1.5 \mathrm{pptv}$ (whichever is larger) for the alkanes and alkynes, and $3 \%$ or 3 pptv (whichever is larger) for the alkenes. The precision of the halocarbon measurements also varies by compound and is $0.8 \%$ for CFC- 11 and CFC- $12,1 \%$ for the other $\mathrm{CFCs}$ and $\mathrm{CCl}_{4} ; 2-4 \%$ for the HCFCs; $5 \%$ for HFC134a and $\mathrm{CH}_{2} \mathrm{Cl}_{2}$; and $2 \%$ for Halon-1211, methyl halides, $\mathrm{C}_{2} \mathrm{Cl}_{4}$, and $\mathrm{CHBr}_{3}$. The measurement accuracy also varies by compound and is $2 \%$ for CFCs (except $5 \%$ for CFC-114); $10 \%$ for the HCFCs, $\mathrm{C}_{2} \mathrm{Cl}_{4}, \mathrm{CH}_{2} \mathrm{Cl}_{2}, \mathrm{CH}_{3} \mathrm{I}$ and $\mathrm{CHBr}_{3}$; and $5 \%$ for Halons, HFC-134a, $\mathrm{CH}_{3} \mathrm{CCl}_{3}, \mathrm{CCl}_{4}, \mathrm{CH}_{3} \mathrm{Cl}, \mathrm{CH}_{3} \mathrm{Br}$, and hydrocarbons. 

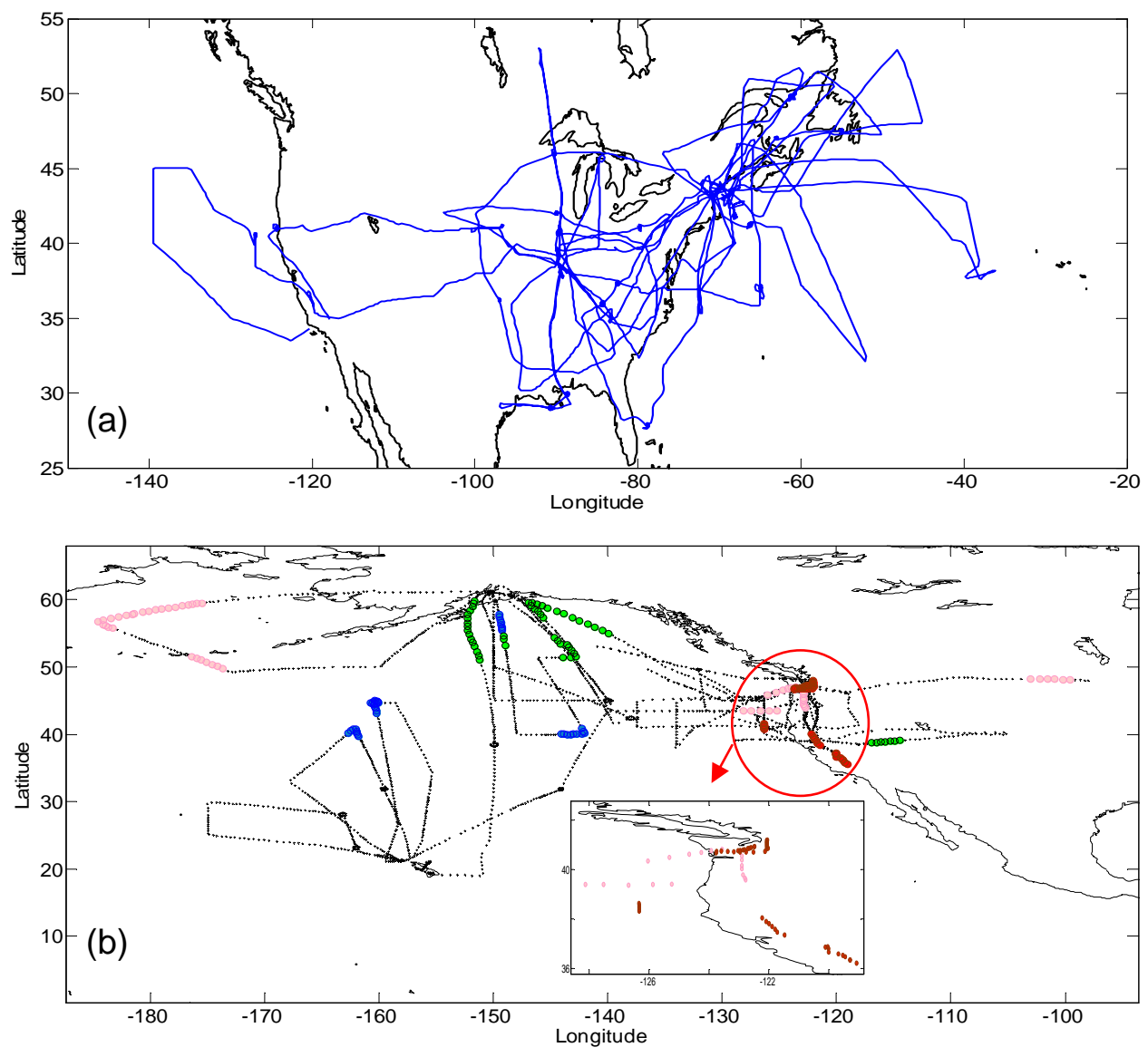

Fig. 1. (a) INTEX-A flight tracks (summer 2004) and (b) INTEX-B flight tracks (spring 2006). In panel (b), colored circles represent the canisters collected within the different plumes: pink circles - Chinese plumes; blue circles - Asian plumes; red circles - US plumes; green circles - stratospherically influenced air masses.

The original standard for the calibration of the NMHCs was gravimetrically prepared from National Bureau of Standards and Scott Specialty Gases standards (accuracy $\pm 5 \%$ ). These standards were used for the calibration of highly pressurized whole air standards ( $2000 \mathrm{psi}$ ) contained within aluminum cylinders. The air was then transferred from the cylinder to an electropolished stainless steel pontoon (34 L) equipped with a Swagelok metal bellows valve, after the initial addition of 17 Torr of degassed ultrapure MilliQ water. A higher degree of stability inside the pontoon has been determined for higher molecular weight hydrocarbons, alkyl nitrates, sulfur species and some of the halocarbons. During the analysis a working standard was analyzed every eight samples, and once a day a series of different standards, including primary standards, were analyzed.

In this paper we also use ozone $\left(\mathrm{O}_{3}\right)$ and carbon monoxide (CO) data measured on both aircraft. In situ $\mathrm{CO}$ measurements were made on the DC- 8 by the differential absorption CO measurement (DACOM) instrument (Sachse et al., 1987); while a CO vacuum UV-resonance fluorescence instrument similar to that of Gerbig et al. (1999) was used on the C-130. The fast response ozone (FASTOS) instrument measured the in situ ozone along the DC-8 flight path (Pearson and Eastman, 1980), and the NCAR 4-channel chemiluminescence instrument was used to measure ozone on the C-130 (Ridley et al., 2004).

\section{Results and discussion}

\subsection{General features}

The vertical profiles of ethyne $\left(\mathrm{C}_{2} \mathrm{H}_{2}\right)$, carbonyl sulfide (OCS), tetrachloroethene $\left(\mathrm{C}_{2} \mathrm{Cl}_{4}\right)$, methyl chloride $\left(\mathrm{CH}_{3} \mathrm{Cl}\right)$, Halon-1211, and HFC-134a show the general trends of the VOCs measured aboard the DC- 8 and C-130 aircraft during this mission (Fig. 2). These species have strong anthropogenic sources and a lifetime long enough to reamin detectable in remote air. Some degree of overall variability in the measured mixing ratios was observed, which is expected to be inversely related to the lifetime of each gas (Junge, 1974). Additional variability was explained by proximity to 

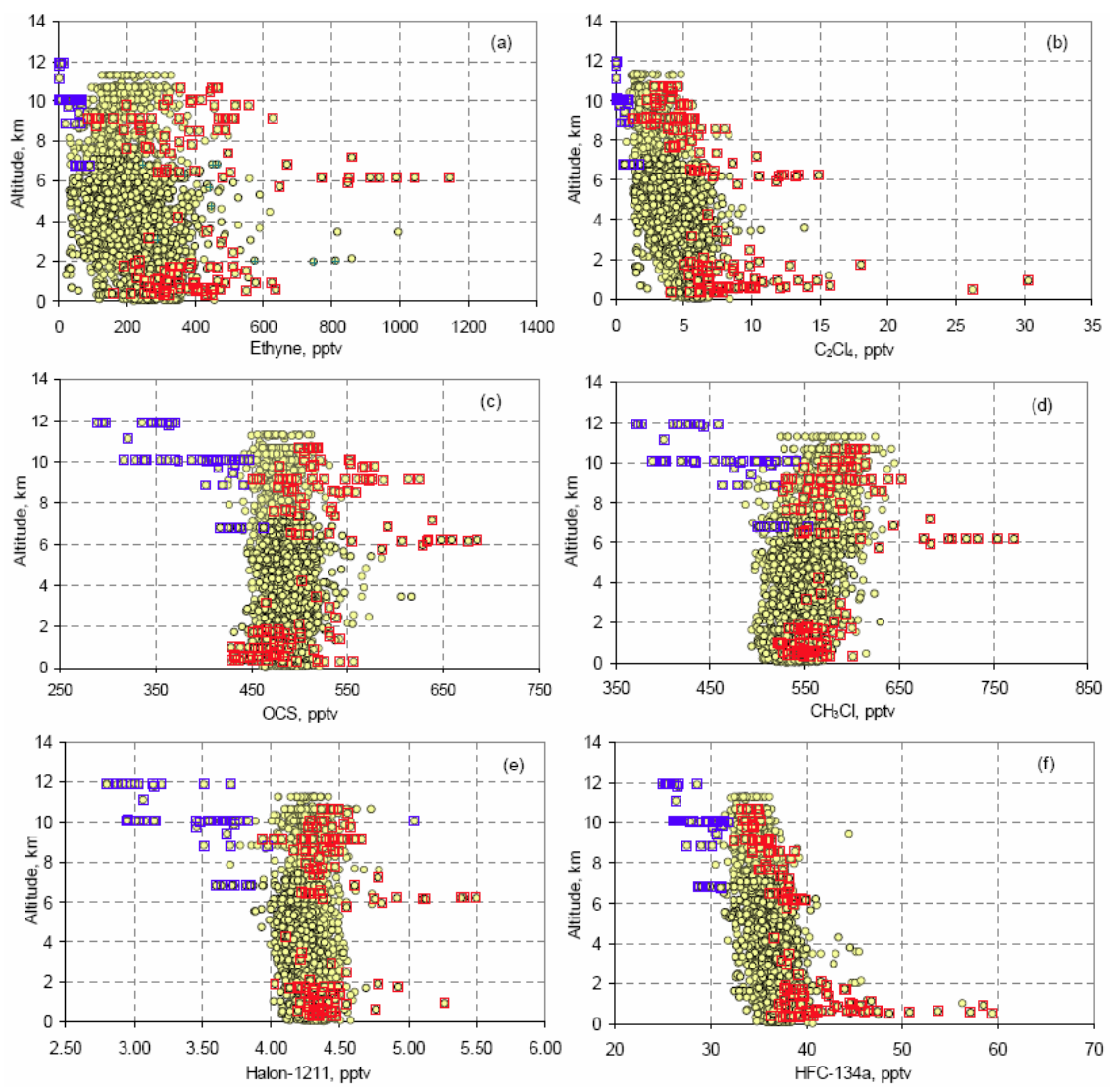

Fig. 2. Vertical profiles of (a) ethyne, (b) $\mathrm{C}_{2} \mathrm{Cl}_{4}$, (c) OCS, (d) $\mathrm{CH}_{3} \mathrm{Cl}$, (e) Halon-1211, and (f) HFC-134a measured during the second phase of INTEX-B (4 April-15 May 2006). Samples included in pollution plumes are highlighted in red; stratospherically influenced air masses are indicated in blue.

or influence by emission sources, as discussed below. Ethyne and $\mathrm{C}_{2} \mathrm{Cl}_{4}$, the most variable among the compounds discussed here, were the shortest-lived with lifetimes of approximately 3 and 16 weeks (Simpson et al., 2004; Xiao et al., 2007) compared to about one year for $\mathrm{CH}_{3} \mathrm{Cl}$ (Khalil and Rasmussen, 1999), 2-7 years for OCS (Xu et al., 2002), 14 years for HFC-134a (McCulloch et al., 2003), and 16 years for Halon-1211 (IPCC, 2007). However, even when the overall variability was considered, we observed mixing ratios that were considerably enhanced with respect to the majority of the samples. These were used to identify air masses recently impacted by anthropogenic emissions. Ethyne is a tracer of general combustion and in many samples the ethyne mixing ratio was more than double the average for all 2441 samples collected from both aircraft $(226 \pm 117$ pptv with a range of 4-1149 pptv), and more than four times the background value calculated as the lower 25th percentile of the INTEXB samples not impacted by stratospheric air. The same feature can be observed for other species with strong anthropogenic sources. For instance, a peak mixing ratio of $30 \mathrm{pptv}$ was observed for $\mathrm{C}_{2} \mathrm{Cl}_{4}(4.4 \pm 2.1 \mathrm{pptv}$ average and $0.1-$ 30.3 pptv range), 5.50 pptv for Halon-1211 (4.26 \pm 0.19 pptv average; $2.80-5.50 \mathrm{pptv}$ range), $772 \mathrm{pptv}$ for $\mathrm{CH}_{3} \mathrm{Cl}$ (554 $\pm 31 \mathrm{pptv}$ average, $372-772 \mathrm{pptv}$ range), $686 \mathrm{pptv}$ for OCS (485 \pm 28 pptv average; $290-686 \mathrm{pptv}$ range), and $60 \mathrm{pptv}$ HFC-134a (36 \pm 3 pptv average; $25-60$ pptv range). For our analysis polluted air masses were identified based on elevated mixing ratios of anthropogenic tracers (i.e. CO, ethyne, $\mathrm{C}_{2} \mathrm{Cl}_{4}$ ) in at least five consecutively collected canisters. We obtained the specific time frame for each pollution event from the open-time of the first canister to the close-time of the last canister. Then, based on the time frame of each pollution episode, we analyzed the kinematic back trajectories along the flight tracks as calculated by the Florida State University FLEXPART model (Stohl et al., 1998). In addition to having elevated mixing ratios in five consecutive air sampling canisters, "pollution plumes" were identified as having passed over source regions at low altitude before being sampled $(<800 \mathrm{hPa}$ pressure altitude; highlighted in red in Fig. 2). The geographical location of the low altitude air masses was considered to be the source region of the pollution plumes. Twelve total plumes were identified: five from China, four from other Asian countries (from now on simply referred to as "Asian" plumes), and three from the 
United States (US plumes) (Fig. 1b and Table 1). Although analysis of the backward trajectories for three of the Asian plumes (\#6, \#7, and \#9) indicates some impact from Chinese air masses (Fig. 3), these pollution plumes were classified as "Asian plumes".

It can be seen in Fig. 2 that not all samples with elevated mixing ratios were included in our definition of pollution plumes because isolated emission sources at small spatial scales can explain high VOC levels in some samples. Conversely, mixing ratios much lower than average were measured in 54 canisters (blue symbols in Fig. 2) due to strong stratospheric influence: these samples were highly enhanced in ozone $(490 \pm 150 \mathrm{ppbv})$ and depleted in many of the CFCs relative to background values (Table 3), e.g. CFC-12 (490 \pm 21 pptv), CFC-11 (212 \pm 17 pptv), HCFC-22 (153 \pm 8 pptv), Halon-1211 (3.42 \pm 0.41 pptv), CO ( $42 \pm 16$ ppbv), ethane ( $204 \pm 155$ pptv), and ethyne ( $37 \pm 24$ pptv).

To investigate the representativeness of the identified pollution plumes, their degree of atmospheric processing was evaluated (air masses recently impacted by VOC sources should be less aged than the remaining INTEX-B samples). Although different methods to evaluate the photochemical processing of air masses exist, hydrocarbon pairs with common sources and different rates of removal are particularly useful to provide the so-called "photochemical clock" (Parrish et al., 1992; McKeen and Liu, 1993; McKeen et al., 1996; Ehhalt et al., 1998; de Gouw et al., 2005; Parrish et al., 2007). In this work, the average $\mathrm{C}_{2} \mathrm{H}_{2} / \mathrm{CO}$ ratio was used to assess aging of the different pollution plumes. Ethyne and $\mathrm{CO}$ are both emitted by combustion sources and their removal from the troposphere is primarily controlled by reaction with $\mathrm{OH}$. Although both species react slowly enough with $\mathrm{OH}$ to easily allow their detection in the remote troposphere, the removal rate of ethyne is faster than $\mathrm{CO}$ resulting in a lifetime of about two-three weeks for $\mathrm{C}_{2} \mathrm{H}_{2}$ (Xiao et al., 2007) versus about two months for CO (Logan et al., 1981). A strong correlation between these two trace gases is usually observed in the troposphere, with a $\mathrm{C}_{2} \mathrm{H}_{2}$ to $\mathrm{CO}$ ratio decreasing with time due to the faster removal rate of ethyne. During TRACE-P, a ratio of $\sim 9 \mathrm{pptv} / \mathrm{ppbv}$ was calculated in a Shanghai urban plume with emissions less than 1 day old (Talbot et al., 2003). Here the US plumes were expected to have the highest $\mathrm{C}_{2} \mathrm{H}_{2} / \mathrm{CO}$ ratio because of the short transport time estimated by the backward trajectories ( 3 days, Table 1). The highest average $\mathrm{C}_{2} \mathrm{H}_{2} / \mathrm{CO}$ ratios were instead observed for the two Chinese plumes encountered by the C130 aircraft $(2.9 \pm 0.3 \mathrm{pptv} / \mathrm{ppbv}$ and $3.5 \pm 0.2 \mathrm{pptv} / \mathrm{ppbv}$, versus a maximum of $2.4 \pm 0.2 \mathrm{pptv} / \mathrm{ppbv}$ for the US plume \#10; Fig. 4). Backward trajectory analysis suggestes that China plume \#4 impacted an emission source region 5 days before sampling, compared to 7 days for China plume \#5 and 3 days for all US plumes (Fig. 5). This is not consistent with the ethyne/CO ratio which suggests less aging in plume \#4 and 5. Instead, the spread in source emission ratio can explain the observed ratios. For instance, a $\mathrm{C}_{2} \mathrm{H}_{2} / \mathrm{CO}$ combustion source ratio of $4.8\left(\times 10^{-3} \mathrm{~mol} / \mathrm{mol}\right)$ was reported for fossil fuel combustion in East Asia, compared to an emission ratio of $2.5\left(\times 10^{-3} \mathrm{~mol} / \mathrm{mol}\right)$ elsewhere, and an emission ratio of $19\left(\times 10^{-3} \mathrm{~mol} / \mathrm{mol}\right)$ was estimated for biofuel versus a ratio of $3.6\left(\times 10^{-3} \mathrm{~mol} / \mathrm{mol}\right)$ for biomass burning (Xiao et al., 2007). This illustrates how the $\mathrm{C}_{2} \mathrm{H}_{2} / \mathrm{CO}$ ratio has to be carefully used when air masses originated from different source regions (and possibly affected by different combustion processes) are compared. In general however the $\mathrm{C}_{2} \mathrm{H}_{2} / \mathrm{CO}$ ratio captured the data set's broad features, namely the lowest value for stratospherically influenced air $(0.5 \mathrm{pptv} / \mathrm{ppbv})$, an intermediate value for samples with no pollution plumes $(1.6 \mathrm{pptv} / \mathrm{ppbv})$, and highest ratios for the pollution plumes $(1.8-3.5 \mathrm{pptv} / \mathrm{ppbv})$. This ultimately points to more recent pollution impact in the twelve identified pollution plumes.

Finally, we recognize that pollution plumes originating from source regions close to each other, such as China and other Asian countries, and intercepted after several days, can undergo to substantial dilution, making the Chinese air masses hard to distinguish from other Asian plumes. Therefore, we investigated the correlation between OCS and $\mathrm{CH}_{3} \mathrm{Cl}$ (recognized coal/biofuel combustion products) versus ethyne (general combustion tracer). Because of the welldocumented widespread use of coal in China (EIA, 2009), a strong correlation between these specific tracers was expected for the Chinese plumes. The correlation was excellent for all of the air masses included in the Chinese plumes $\left(R^{2} 0.66-0.98\right)$ while weak correlations were observed for the Asian plumes $\left(0.05-0.53 R^{2}\right)$ (Table 2). These findings are consistent with plumes \#1-\#5 being impacted by Chinese emissions.

\subsection{Pollution plumes}

Table 3 lists the statistics calculated for the different categories of identified pollution plumes. The majority of the enhanced VOC pollution plumes were encountered over the Pacific between about $40-60^{\circ} \mathrm{N}$ (Fig. 1b). Four of the five Chinese plumes were sampled far away from the source region: two over the Pacific ocean very close to the west coast of the United States $\left(43-46^{\circ} \mathrm{N} ; 123-126^{\circ} \mathrm{W}\right)$ and two inland - one over Oregon $\left(44-46^{\circ} \mathrm{N} ; 123^{\circ} \mathrm{NW}\right)$ and one over North Dakota $\left(48^{\circ} \mathrm{N} ; 100-103^{\circ} \mathrm{W}\right)$. The fifth Chinese plume, the four Asian plumes, and the stratospherically influenced air masses were all sampled over the Eastern Pacific region. Air masses that had recently passed at low altitude over the United States (i.e. US pollution plumes) were also encountered inland of the US.

Five major Asian plumes, extending from the northeastern Pacific to northwestern Atlantic, were previously measured over North America during INTEX-A (see Liang et al., 2007 for their specific location). For many VOCs, the mixing ratios measured in the INTEX-A Asian plumes were considerably lower than those measured in the INTEX-B 
Table 1. Summary of VOC pollution plumes sampled during the second half of INTEX-B (4 April-15 May 2006).

\begin{tabular}{lccc}
\hline & $\begin{array}{c}\text { Transport time } \\
\text { (days) }\end{array}$ & $\begin{array}{c}\text { Number of } \\
\text { samples }\end{array}$ & $\begin{array}{c}\text { Aircraft }- \\
\text { Flight date }\end{array}$ \\
\hline Chinese plumes & 7 & 5 & DC-8 - 17 Apr 2006 \\
Plume \# 1 & 5 & 29 & DC-8 - 12 May 2006 \\
Plume \# 2 & 7 & 6 & DC-8 - 15 May 2006 \\
Plume \# 3 & 5 & 6 & C-130 - 1 May 2006 \\
Plume \# 4 & 7 & 7 & C-130 - 1 May 2006 \\
Plume \# 5 & & & \\
Asian plumes & 5 & 15 & DC-8 - 25 Apr 2006 \\
Plume \# 6 & 5 & 10 & DC-8 - 7 May 2006 \\
Plume \# 7 & 7 & 8 & DC-8 - 7 May 2006 \\
Plume \# 8 & & & DC-8 - 23 Apr 2006 \\
Plume \# 9 & 3 & 23 & C130 - 24 Apr 2006 \\
US Plumes & 3 & 17 & C130 - 3 May 2006 \\
Plume \# 10 & 3 & 14 & DC8 - 15 May 2006 \\
Plume \# 11 & & & \\
Plume \# 12 & & & \\
\hline
\end{tabular}

* Transport time estimated using kinematic back trajectories.
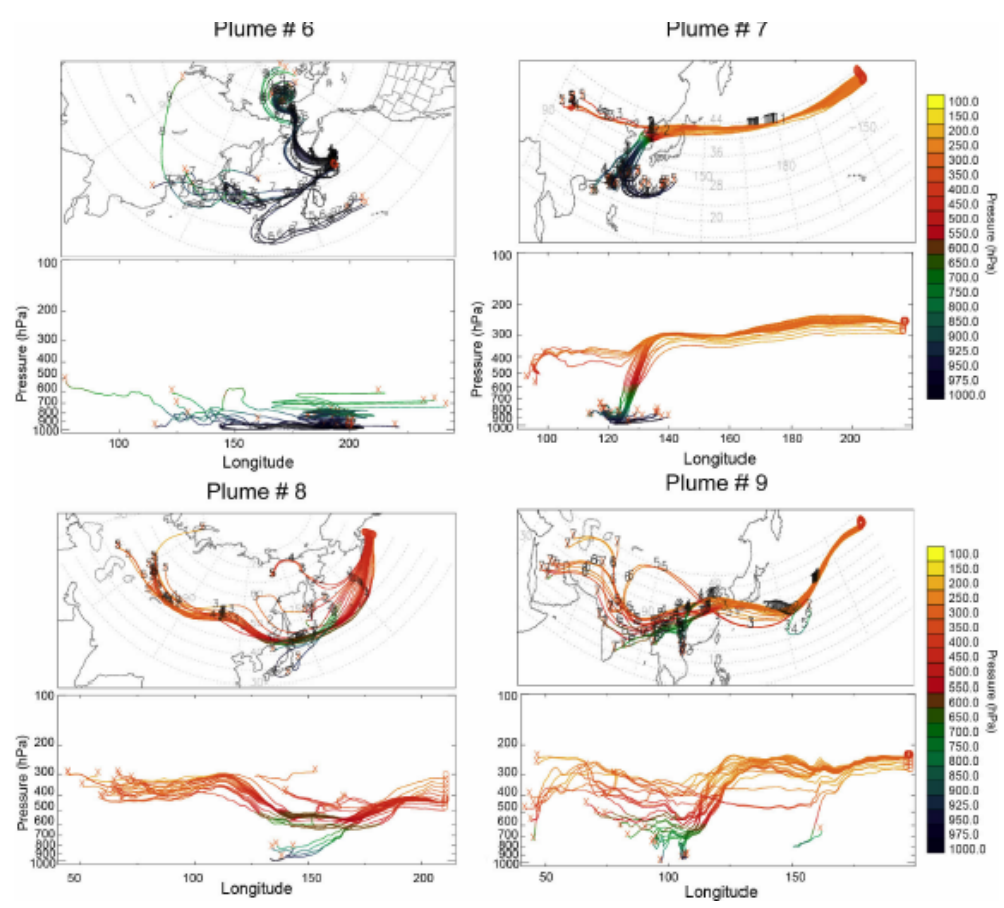

Fig. 3. Kinematic back trajectories for Asian plumes \#6 (10-day back trajectories), \#7 (5-day back trajectories) \#8 and \#9 (7-day back trajectories). Backward trajectories started at the pressure level, latitude and longitude of the aircraft. Time is labeled along the trajectories and each trajectory is color-coded by the pressure level that it was located at throughout its duration.

Asian plumes (i.e. Chinese plumes and Asian plumes). For instance, average ethane, ethyne and benzene mixing ratios of $880 \pm 190 \mathrm{pptv}, 160 \pm 40 \mathrm{pptv}$, and $24 \pm 11 \mathrm{pptv}$ were reported in 2004 for Asian plumes, versus respective averages of $1350 \pm 376 \mathrm{pptv}, 428 \pm 209 \mathrm{pptv}$, and $105 \pm 75 \mathrm{pptv}$ for all the Asian and Chinese plumes encountered during INTEX-B. The lower VOC levels measured during INTEXA were mainly the result of the enhanced photochemical decomposition of the VOCs during the summer, but also influenced by longer summertime transport of Asian pollution 


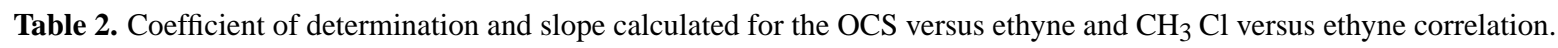

\begin{tabular}{lll}
\hline & $\begin{array}{l}\text { OCS vs. Ethyne } \\
R^{2} \text { (slope) }\end{array}$ & $\begin{array}{l}\mathrm{CH}_{3} \mathrm{Cl} \text { vs. Ethyne } \\
R^{2} \text { (slope) }\end{array}$ \\
\hline Plume \#1 & $0.91(0.21)$ & $0.96(0.26)$ \\
Plume \#2 & $0.87(0.28)$ & $0.66(0.17)$ \\
Plume \#3 & $0.97(0.27)$ & $0.73(0.15)$ \\
Plume \#4 & $0.97(0.19)$ & $0.93(0.26)$ \\
Plume \#5 & $0.98(0.23)$ & $0.96(0.26)$ \\
All samples in Chinese plumes & $0.92(0.22)$ & $0.91(0.22)$ \\
Plume \#6 & $0.53(0.17)$ & $0.53(0.14)$ \\
Plume \#7 & $0.26(0.14)$ & $0.05(-0.05)$ \\
Plume \#8 & $0.06(0.02)$ & $0.29(0.10)$ \\
Plume \#9 & $0.53(0.11)$ & $0.48(0.13)$ \\
All samples in Asian plumes & $0.17(0.09)$ & $0.10(0.08)$ \\
\hline
\end{tabular}

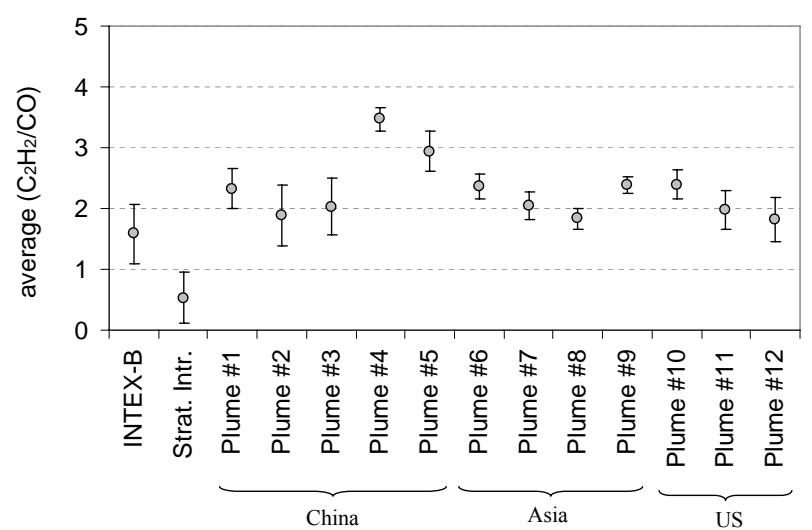

Fig. 4. Average ethyne/CO ratio calculated for the different pollution plumes, for the stratospherically influenced air masses, and for the remaining INTEX-B samples collected (non-plume data).

across the Pacific. We recognize that other factors can affect the levels of trace gases in troposphere, for example source and sink strengths, the predominant meteorology, and the geographical location of the air masses (i.e. latitude).

To evaluate the enhancement of the VOCs measured in the INTEX-B pollution plumes, the lowest 25th percentile of all of C-130 and DC-8 samples was calculated and averaged (after the stratospheric samples had been removed) and compared to the background from the INTEX-A mission, also the average of the lowest quartile of the data without stratospheric influence (Table 3). The INTEX-B background was considered to represent the background of the northern Pacific region at the time of this sampling campaign, while the 2004 background levels measured during INTEXA were mostly influenced by the northern Atlantic region. Overall, the average mixing ratios calculated for most of the trace gases in spring 2006 were not significantly different than the 2004 summer background (Table 3). How- ever, some differences were worth noting. First, a decline of $2 \%$ in both CFC-12 and CFC-113 was observed, from $536 \pm 2$ pptv in 2004 to $525 \pm 4$ pptv in 2006 for CFC- 12 and from $78.0 \pm 0.5 \mathrm{pptv}$ (INTEX-A) to $76.5 \pm 0.8 \mathrm{pptv}$ (INTEXB) for CFC-113, which lies outside the statistical uncertainty. Long-term global monitoring networks have also shown that the global tropospheric mixing ratios of these species are declining, although at a slower rate that we measured (about $0.5-0.9 \%$ between 2004 and 2006; CFC-12 and CFC-113 data from the NOAA/ESRL halocarbons in situ program; NOAA/ESRL, 2008). On the contrary, we measured CFC11 levels that were not statistically different in spite of the negative global trends observed in recent years for this trace gas (NOAA/ESRL, 2008). Higher background levels were observed in 2006 than in 2004 for other VOCs, namely OCS, HFC-134a, HCFC-142b, methylene chloride, methyl chloride, 1,2-dichloroethane, ethane, and ethyne. For long-lived VOCs (e.g. CFC replacements) the higher levels in 2006 were most likely the result of increased emissions over time, or differences in the north Atlantic and Pacific regions. For the remaining trace gases with shorter lifetimes, including the relatively long lived OCS (2-7 years, Xu et al., 2002) and $\mathrm{CH}_{3} \mathrm{Cl}(\sim 1$ year Khalil and Rasmussen, 1999), the different season (spring for INTEX-B and summer for INTEXA, with an average interval of 90 days) accounts for most of the observed differences. In particular, a seasonal variation in the order of about 50 pptv for OCS (Montzka et al., 2007) and 40 pptv for $\mathrm{CH}_{3} \mathrm{Cl}$ (Yoshida et al., 2004) is observed in the Northern Hemisphere between the spring and the summer period. These values are consistent with the differences calculated between INTEX-A and INTEX-B (63 pptv for OCS and 31 pptv $\mathrm{CH}_{3} \mathrm{Cl}$, respectively, Table 3 ).

Many gases were significantly enhanced in the plumes with respect to the background air (over $2 \sigma$ above the INTEX-B background, noted in bold in Table 3). All of the plumes were enhanced in ozone, $\mathrm{CO}, \mathrm{CS}_{2}$, Halon-1211, HCFC-22, HCFC-142b, HCFC-141b, chloroform $\left(\mathrm{CHCl}_{3}\right)$, 

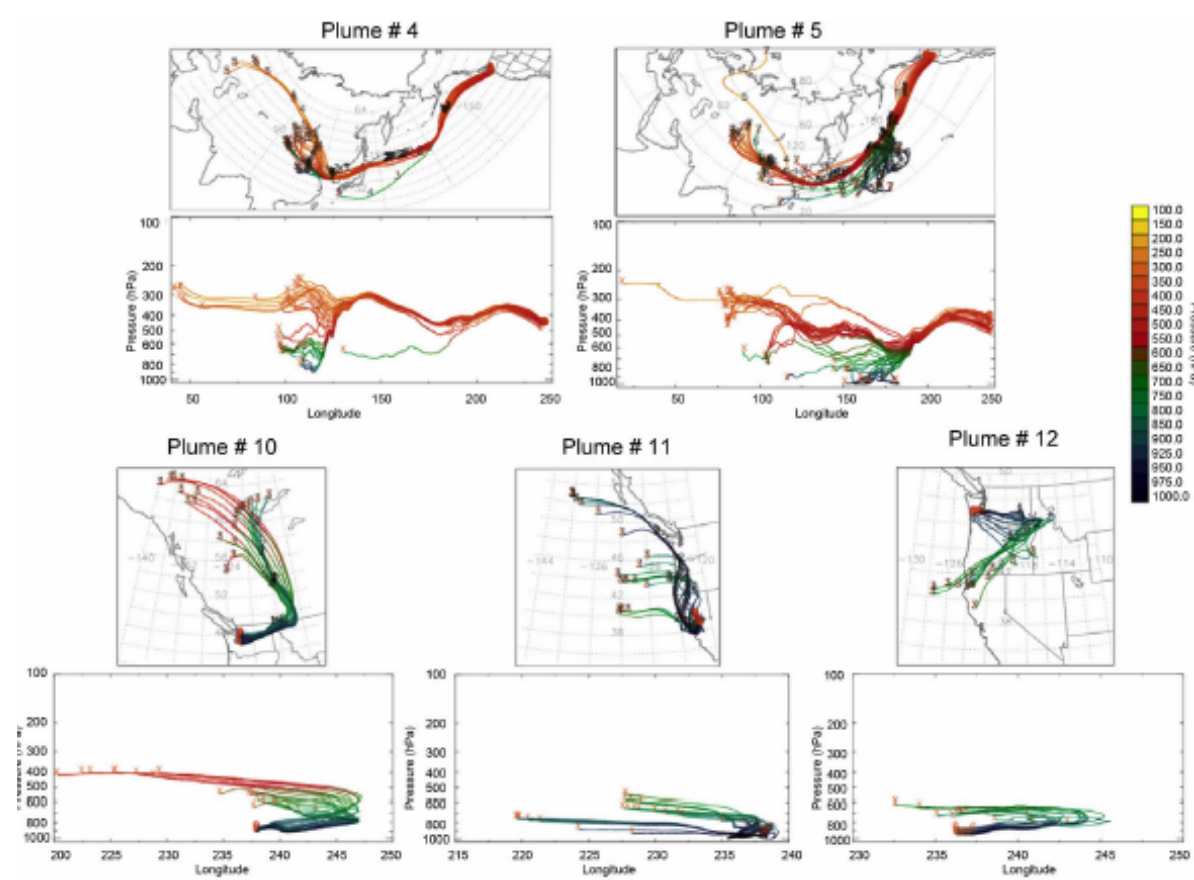

Fig. 5. Kinematic back trajectories for Chinese plumes \#4 (5-day back trajectories), and \#5 (7-day back trajectories) and US plumes \#10, \#11 and \#12 (3-day back trajectories). Backward trajectories started at the pressure level, latitude and longitude of the aircraft. Time is labeled along the trajectories and each trajectory is color-coded by the pressure level that it was located at throughout its duration.

methylene chloride $\left(\mathrm{CH}_{2} \mathrm{Cl}_{2}\right)$, trichloroethene $\left(\mathrm{C}_{2} \mathrm{HCl}_{3}\right)$, tetrachloroethene $\left(\mathrm{C}_{2} \mathrm{Cl}_{4}\right)$, methyl bromide $\left(\mathrm{CH}_{3} \mathrm{Br}\right)$, methyl iodide $\left(\mathrm{CH}_{3} \mathrm{I}\right)$, ethylchloride, 1,2-dichloroethane (1,2-DCE), ethane, ethyne, propane, butanes, $i$-pentane, and benzene. The elevated mixing ratios of all of these species (with the exception of $\mathrm{CH}_{3} \mathrm{Br}$ and $\mathrm{CH}_{3} \mathrm{I}$, which have strong biogenic sources) highlight the anthropogenic influence within these air masses. Particularly interesting was the source characterization of certain enhancements. For instance, OCS and $\mathrm{CH}_{3} \mathrm{Cl}$ were significantly higher than background levels only in the Asian and Chinese plumes. Among the CFC replacements, HFC-134a was particularly elevated in air masses influenced by US emissions. An average mixing ratio of $43 \pm 5$ pptv was measured in the three US plumes, representing a $25 \%$ enhancement compared to the background of $34.3 \pm 0.9$ pptv (Fig. 6). Both the Asian and Chinese plumes also showed elevated HFC-134a levels, but with lower enhancements than the US air masses: $37 \pm 2$ pptv measured in the Asian plumes (8\% enhancement) and, $36 \pm 4$ pptv in the Chinese air masses $(\sim 6 \%$ enhancement). Chinese plumes $\# 2$ and \#3 (and to some extent plume \#1) were diluted compared to the other Chinese air masses, and the average mixing ratios for many species were not significantly different than background levels (Table 4). When Chinese plumes \#2 and \#3 were excluded, the HFC-134a enhancement was $38 \pm 1$ pptv (11\% enhancement). Further, when plumes \#4 and \#5 were considered separately from the other three Chinese air masses, the trace gas mixing ratios showed a con- siderable increase with respect to background levels. For instance, the average $\mathrm{OCS}$ and $\mathrm{CH}_{3} \mathrm{Cl}$ mixing ratios were about $30 \%$ higher than background when the 13 samples included in these two plumes were considered $(622 \pm 44 \mathrm{pptv}$ for OCS, $687 \pm 53$ pptv for $\mathrm{CH}_{3} \mathrm{Cl}$ ). An average Halon1211 mixing ratio of $4.90 \pm 0.39 \mathrm{pptv}$ was measured in the same plumes (\#4 and \#5), representing an enhancement over background of $18 \%$. Finally, elevated levels of industrial halogenated solvents were also observed in the Chinese air masses. In particular, high enhancements of chloroform (up to $37 \mathrm{pptv}$ average), methylene chloride (up to $135 \mathrm{pptv}$ ), and trichloroethene (up to $6.6 \mathrm{pptv}$ ) were measured in pollution plume \#4.

\subsection{Halon-1211}

Halon-1211 is an anthropogenic brominated compound widely used in fire-fighting equipment. It is the most abundant halon in the atmosphere and its production and consumption is regulated under the Montreal Protocol and subsequent amendments. In particular, a complete phase-out of the base levels in Halon-1211 production and consumption was established for developed countries in 1994, while developing countries were required to reduce emissions by half - relative to the 1995-1997 base level - by 1 January 2005 (UNEP, 2003). The uncontrolled release of Halon1211 from the large halon stocks that are still present is an additional important source that also needs to be considered 
Table 3. Average mixing ratio (pptv, unless otherwise specified; \pm 1 -sigma SD) measured in pollution plumes sampled during INTEXB. Mixing ratios enhanced with respect to the background ( \pm 2-sigma SD) are reported in bold. The background levels observed during INTEX-B and INTEX-A are also listed (see text for background calculation). 1,2-DCE = 1,2 dichloroethane.

\begin{tabular}{|c|c|c|c|c|c|}
\hline & $\begin{array}{l}\text { Chinese } \\
\text { plumes }\end{array}$ & $\begin{array}{l}\text { Asian } \\
\text { plumes }\end{array}$ & $\begin{array}{c}\text { US } \\
\text { plumes }\end{array}$ & $\begin{array}{c}\text { INTEX-B } \\
\text { Background air }\end{array}$ & $\begin{array}{c}\text { INTEX-A } \\
\text { Background air }\end{array}$ \\
\hline Ozone, ppbv & $84(29)$ & $73(16)$ & $63(7)$ & $46(7)$ & $45(9)$ \\
\hline $\mathrm{CO}, \mathrm{ppbv}$ & 184 (49) & $181(21)$ & $166(22)$ & $110(13)$ & $85(8)$ \\
\hline OCS & $548(62)$ & 519 (19) & 465 (19) & $469(9)$ & $406(24)$ \\
\hline $\mathrm{CS}_{2}$ & $12.7(8.9)$ & $6.7(3.5)$ & $10.2(6.0)$ & $3.0(0.6)$ & \\
\hline CFC-12 & $529(5)$ & $529(6)$ & $531(5)$ & $525(4)$ & $536(2)$ \\
\hline CFC-11 & $248(4)$ & $250(3)$ & $250(2)$ & $247(3)$ & $252(2)$ \\
\hline CFC-113 & $77.4(0.9)$ & $77.1(1.3)$ & $77.7(0.7)$ & $76.5(0.8)$ & $78.0(0.5)$ \\
\hline CFC-114 & $14.8(0.2)$ & $14.8(0.2)$ & $14.8(0.1)$ & $14.6(0.1)$ & $14.5(0.1)$ \\
\hline Halon-1211 & $4.49(0.31)$ & $4.38(0.10)$ & $4.37(0.19)$ & $4.17(0.07)$ & $4.22(0.05)$ \\
\hline Halon-2402 & $0.48(0.01)$ & $0.48(0.02)$ & $0.49(0.01)$ & $0.48(0.01)$ & $0.53(0.01)$ \\
\hline Halon-1301 & $3.06(0.07)$ & $3.06(0.06)$ & $3.12(0.06)$ & $3.03(0.03)$ & \\
\hline HFC-134a & $36.1(4.0)$ & $36.7(1.9)$ & $42.8(5.3)$ & $34.3(0.9)$ & $29.8(0.8)$ \\
\hline HCFC-22 & $181(11)$ & $180(4)$ & 185 (11) & $169(3)$ & $164(2)$ \\
\hline HCFC-142b & $17.0(1.3)$ & $16.4(0.6)$ & $17.3(1.0)$ & $15.5(0.3)$ & $14.6(0.2)$ \\
\hline HCFC-141b & $19.9(2.3)$ & $19.9(0.7)$ & $20.1(1.1)$ & $18.0(0.5)$ & $17.2(0.4)$ \\
\hline $\mathrm{CHCl}_{3}$ & $14.9(6.0)$ & $12.4(1.5)$ & $12.5(1.5)$ & $8.0(0.8)$ & $7.8(0.7)$ \\
\hline $\mathrm{CCl}_{4}$ & $95(2)$ & $94(2)$ & $94(1)$ & $93(1)$ & $94(1)$ \\
\hline $\mathrm{CH}_{2} \mathrm{Cl}_{2}$ & $54.2(24.4)$ & $48.8(7.4)$ & $44.0(8.4)$ & $28.4(3.0)$ & $19.4(1.8)$ \\
\hline $\mathrm{C}_{2} \mathrm{HCl}_{3}$ & $1.57(1.90)$ & $1.46(1.17)$ & $1.58(1.82)$ & $0.22(0.07)$ & \\
\hline $\mathrm{C}_{2} \mathrm{Cl}_{4}$ & $5.9(4.8)$ & $5.7(1.9)$ & $9.4(4.8)$ & $2.4(0.5)$ & $2.3(0.5)$ \\
\hline $\mathrm{CH}_{3} \mathrm{Cl}$ & $604(57)$ & $584(21)$ & $548(13)$ & $531(11)$ & $500(13)$ \\
\hline $\mathrm{CH}_{3} \mathrm{Br}$ & $8.9(1.1)$ & $8.8(0.5)$ & $10.9(10.2)$ & $7.7(0.2)$ & $7.6(0.3)$ \\
\hline $\mathrm{CH}_{3} \mathrm{I}$ & $0.12(0.10)$ & $0.19(0.17)$ & $0.28(0.22)$ & $0.05(0.01)$ & $0.05(0.01)$ \\
\hline $\mathrm{CHBr}_{3}$ & $0.63(0.26)$ & $0.81(0.52)$ & $0.94(0.24)$ & $0.33(0.09)$ & $0.25(0.07)$ \\
\hline Ethylchloride & $11.4(8.5)$ & $7.4(1.8)$ & $6.6(1.6)$ & $2.9(0.5)$ & \\
\hline 1,2-DCE & $39.7(34.7)$ & $18.4(5.4)$ & $13.1(1.1)$ & $7.8(1.5)$ & $3.1(0.5)$ \\
\hline Ethane & 1319 (407) & 1391 (319) & $1608(306)$ & $750(136)$ & $500(85)$ \\
\hline Ethene & $17(85)$ & $10(6)$ & 117 (136) & $7(2)$ & $6(2)$ \\
\hline Ethyne & $453(228)$ & $396(85)$ & $356(104)$ & $126(33)$ & $52(15)$ \\
\hline Propane & $358(262)$ & $276(110)$ & 505 (232) & $73(25)$ & $51(20)$ \\
\hline$i$-Butane & $41(37)$ & $29(11)$ & $66(46)$ & $10(2)$ & $6(2)$ \\
\hline$n$-Butane & 64 (116) & $48(19)$ & $166(143)$ & $11(3)$ & $9(3)$ \\
\hline$i$-Pentane & $32(95)$ & $16(7)$ & 139 (127) & $6(2)$ & $6(2)$ \\
\hline$n$-Pentane & $20(40)$ & $11(5)$ & $60(54)$ & $5(2)$ & $4(1)$ \\
\hline Benzene & 124 (79) & $82(30)$ & $82(32)$ & $19(6)$ & $9(2)$ \\
\hline Toluene & $22(67)$ & $10(5)$ & $75(73)$ & $5(2)$ & $4(1)$ \\
\hline No. samples & 53 & 41 & 52 & & \\
\hline
\end{tabular}

(Montzka, 2003). Because of the long lifetime of Halon1211 (16 years; IPCC, 2007), reduced production and consumption in developing countries will manifest as a slow decrease of halons in the atmosphere. The Chinese plumes encountered during INTEX-B offer an excellent opportunity to evaluate whether the 1 January 2005 deadline is producing any change in the local and global atmospheric levels of this species, and to see whether Halon-1211 can still be considered a specific tracer for Chinese air masses as it has been in previous studies such as TRACE-P (Blake et al., 2003).
The highest Halon-1211 levels were measured in the Chinese plumes encountered on the $\mathrm{C}-130$, with average mixing ratios of $5.19 \pm 0.29$ pptv (plume \#4, $24 \%$ enhancement over background) and $4.65 \pm 0.27 \mathrm{pptv}$ (plume \#5, $11 \%$ enhancement) compared to a background of $4.17 \pm 0.07 \mathrm{pptv}$ (Fig. 7, Table 4). Lower average levels were measured for the remaining samples in the Chinese plumes $(4.36 \pm 0.16 \mathrm{pptv})$. Although these levels all represent a significant increase over background (particularly for plumes \#4 and \#5), we note that very much higher enhancements were found in 
Table 4. Average mixing ratio (pptv, unless otherwise indicated) of the five Chinese pollution plumes. The one sigma standard deviation is reported in parenthesis. $\mathrm{ND}=$ below detection limit.

\begin{tabular}{|c|c|c|c|c|c|c|}
\hline & Background & Plume \#1 & Plume \#2 & Plume \#3 & Plume \#4 & Plume \#5 \\
\hline Ozone, ppbv & $46(7)$ & $64(4)$ & $81(39)$ & $63(5)$ & $108(9)$ & $110(13)$ \\
\hline $\mathrm{CO}, \mathrm{ppbv}$ & $110(13)$ & $173(25)$ & $156(44)$ & 177 (47) & 273 (24) & $238(42)$ \\
\hline OCS & 469 (9) & $524(24)$ & $522(47)$ & $533(44)$ & 649 (22) & 599 (47) \\
\hline $\mathrm{CS}_{2}$ & $3.0(0.6)$ & $13.8(3.3)$ & $10.4(7.4)$ & $4.2(0.9)$ & $29.3(10.1)$ & $15.0(5.2)$ \\
\hline CFC -12 & $525(4)$ & $530(7)$ & $529(5)$ & $523(3)$ & $530(3)$ & $531(5)$ \\
\hline CFC-11 & 247 (3) & $252(4)$ & $248(3)$ & $243(1)$ & $250(3)$ & $249(1)$ \\
\hline CFC-113 & $76.5(0.8)$ & $78.3(0.9)$ & $77.1(0.8)$ & $76.8(0.5)$ & $78.3(0.9)$ & $77.9(0.6)$ \\
\hline CFC-114 & $14.6(0.1)$ & $14.9(0.1)$ & $14.8(0.2)$ & $14.7(0.1)$ & $15.0(0.2)$ & $14.8(0.2)$ \\
\hline Halon-1211 & $4.17(0.07)$ & $4.39(0.10)$ & $4.36(0.17)$ & $4.35(0.14)$ & $5.19(0.29)$ & $4.65(0.27)$ \\
\hline Halon-2402 & $0.48(0.01)$ & $0.49(0.01)$ & $0.48(0.01)$ & $0.48(0.01)$ & $0.48(0.01)$ & $0.48(0.01)$ \\
\hline Halon-1301 & $3.03(0.03)$ & $3.08(0.03)$ & $3.07(0.07)$ & $3.01(0.02)$ & $3.07(0.07)$ & $3.08(0.04)$ \\
\hline HFC-134a & $34.3(0.9)$ & $36.9(1.2)$ & $35.1(1.1)$ & $34.7(0.8)$ & $38.9(0.5)$ & $38.2(0.8)$ \\
\hline HCFC-22 & $169(3)$ & $181(5)$ & $175(6)$ & $174(4)$ & $201(5)$ & $191(9)$ \\
\hline HCFC-142b & $15.5(0.3)$ & $16.7(0.5)$ & $16.4(0.7)$ & $15.9(0.7)$ & $19.7(1.0)$ & $18.4(1.1)$ \\
\hline HCFC-141b & $18.0(0.5)$ & $19.9(0.8)$ & $18.3(0.7)$ & $18.5(0.5)$ & $25.4(1.4)$ & $22.9(1.9)$ \\
\hline $\mathrm{CHCl}_{3}$ & $8.0(0.8)$ & 13.4 (1.7) & $11.0(3.0)$ & 13.2 & $28.7(4.5)$ & $22.1(5.4)$ \\
\hline $\mathrm{CCl}_{4}$ & $93(1)$ & $97(2)$ & $93(2)$ & $94(1)$ & $97(2)$ & $97(2)$ \\
\hline $\mathrm{CH}_{2} \mathrm{Cl}_{2}$ & $28.4(3.0)$ & $50.7(9.6)$ & $37.9(9.3)$ & $44.0(6.0)$ & $113.2(13.3)$ & $82.4(20.5)$ \\
\hline $\mathrm{C}_{2} \mathrm{HCl}_{3}$ & $0.22(0.07)$ & $1.70(0.85)$ & $0.59(0.34)$ & $0.50(0.15)$ & $5.72(0.85)$ & $2.89(1.11)$ \\
\hline $\mathrm{C}_{2} \mathrm{Cl}_{4}$ & $2.4(0.5)$ & $6.5(1.2)$ & $3.9(1.3)$ & $4.2(1.0)$ & $12.8(12.0)$ & $9.5(2.1)$ \\
\hline $\mathrm{CH}_{3} \mathrm{Cl}$ & $531(11)$ & $610(28)$ & $573(32)$ & 571 (29) & $720(30)$ & $658(52)$ \\
\hline $\mathrm{CH}_{3} \mathrm{Br}$ & $7.7(0.2)$ & $9.3(1.0)$ & $8.2(0.5)$ & $8.2(0.4)$ & $11.0(0.9)$ & $10.1(1.2)$ \\
\hline $\mathrm{CH}_{3} \mathrm{I}$ & $0.05(0.01)$ & $0.10(0.02)$ & $0.06(0.04)$ & $0.03(0.01)$ & $0.34(0.06)$ & $0.28(0.07)$ \\
\hline $\mathrm{CHBr}_{3}$ & $0.33(0.09)$ & $0.84(0.17)$ & $0.57(0.28)$ & $0.40(0.08)$ & $0.82(0.11)$ & $0.75(0.10)$ \\
\hline Ethylchloride & $2.9(0.5)$ & $7.9(2.9)$ & $6.2(3.1)$ & $7.4(2.3)$ & 29.7 (7.9) & $23.1(8.6)$ \\
\hline 1,2-DCE & $7.8(1.5)$ & $24.3(7.4)$ & 19.3 (11.4) & $24.0(9.9)$ & $119.6(23.4)$ & $80.2(36.0)$ \\
\hline Ethane & 750 (136) & $1265(82)$ & $1116(292)$ & $1091(226)$ & $2025(82)$ & $1790(180)$ \\
\hline Ethene & 7 (2) & ND & $13(8)$ & ND & $36(15)$ & $12(4)$ \\
\hline Ethyne & $126(33)$ & 408 (108) & 313 (156) & $372(161)$ & 949 (112) & $711(200)$ \\
\hline Propane & $73(25)$ & $244(60)$ & $223(162)$ & $168(60)$ & $851(64)$ & 737 (99) \\
\hline$i$-Butane & $10(2)$ & $28(11)$ & $28(18)$ & $18(6)$ & $99(9)$ & 64 (17) \\
\hline$n$-Butane & $11(3)$ & $43(18)$ & $49(44)$ & $27(10)$ & $144(11)$ & $99(22)$ \\
\hline$i$-Pentane & $6(2)$ & $17(4)$ & $22(11)$ & $10(4)$ & $83(13)$ & $45(13)$ \\
\hline$n$-Pentane & $5(2)$ & $12(3)$ & $16(11)$ & $6(1)$ & $47(5)$ & $27(7)$ \\
\hline Benzene & 19 (6) & $102(34)$ & 78 (49) & 67 (36) & $300(33)$ & $214(67)$ \\
\hline Toluene & $5(2)$ & $14(3)$ & $6(2)$ & $9(3)$ & $66(23)$ & $22(6)$ \\
\hline
\end{tabular}

the Shanghai plume encountered during the TRACE-P study (13.5 $\pm 8.2 \mathrm{pptv}$, with values up to $27.6 \mathrm{pptv})$. Moreover, high Halon-1211 mixing ratios were measured using our sampling canisters in ground-level air samples collected in September 2005 in two major urban centers of China's Pearl River Delta region, Guangzhou: $31 \pm 34$ pptv (6.0160 pptv; $n=42)$ and Dongguan: $11 \pm 8.2$ pptv (4.8 -53 pptv; $n=48$ ) (Blake, D. R., unpublished data). Our data suggested that Halon-1211 sources are diminishing in China and that remaining sources are not evenly distributed in China, with some regions attaining near-background mixing ratios especially as compared to a few years ago. We anticipate that this trace gas will continue to decrease its role as a "specific" Chinese tracer, as suggested by the relatively low levels measured in other Chinese plumes encountered during INTEX-B. Moreover, the global average Halon-1211 is no longer increasing in the remote troposphere. The background Halon-1211 mixing ratio measured by global monitoring networks was 4.16 pptv in 2006 versus $4.15 \mathrm{pptv}$ in 2005 (NOAA/GMD, 2008), which is in good agreement with the background of $4.17 \pm 0.07 \mathrm{pptv}$ we report from the 2006 INTEX-B campaign. It is worth noting that 5 out of the 54 samples included in the US polluted air masses had Halon-1211 mixing ratios higher than 


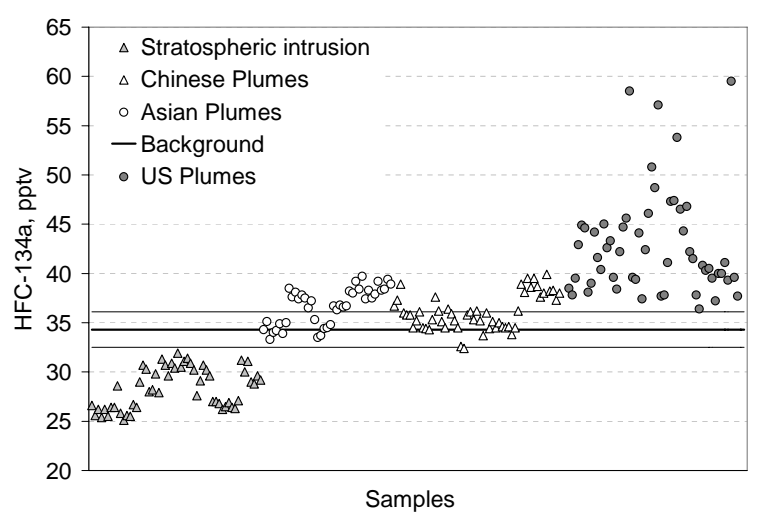

Fig. 6. HFC-134a mixing ratios measured in the different pollution plumes identified. The 2- $\sigma$ SD calculated for the background is reported by the thin black lines above and below the thick background line.

4.50 pptv, representing an increase of about $10 \%$ with respect to the background. Persisting emissions of this halogenated compound in urban/industrial northeastern United States were observed in a previous study during 1996-1998 (Barnes et al., 2003). Significant emissions of selected restricted halocarbons (including Halon-1211) in the continental United States and Canada were also estimated by Hurst et al. (2006) for 2003. More recently, an average Halon-1211 mixing ratio of $5.57 \pm 0.49 \mathrm{pptv}$ was measured in Los Angeles in 2005 (total of 10 ground level air samples; A. Beyersdorf, in preparation, 2009). The enhanced Halon-1211 levels in a few US plume samples during INTEX-B suggest that sources of Halon-1211 were still present in the North American continent in 2006.

\subsection{Trace gas relationships}

Cross correlation analysis of selected species is a useful tool to identify specific VOC sources. It is known that the most important combustion sources for OCS are coal and biofuel combustion and biomass burning (Khalil and Rasmussen, 1984; Chin and Davis, 1993; Watts, 2000). To isolate the biomass burning source, the OCS to $\mathrm{CO}$ enhancement ratio was considered. Emission ratios of $0.054 \mathrm{pptv} / \mathrm{ppbv}$ and $0.10 \mathrm{pptv} / \mathrm{ppbv}$ have been observed for "pure" biomass burning plumes (Meinardi et al., 2003; Blake et al., 2004). Higher ratios have been measured in several Chinese urban plumes (0.35-0.96 pptv/ppbv, Blake et al., 2004) where coal and biofuel combustion were the most likely sources. The analysis of correlation plots from INTEX-B pollution plumes reveal that a strong correlation was observed only in Chinese air masses, with a high coefficient of determination, $R^{2}$ (0.80-0.96) (Fig. 8). A weaker correlation was found for Asia plume \#6, which was partially influenced by air masses from China $\left(0.59 R^{2}\right.$; plot not shown), while a lack

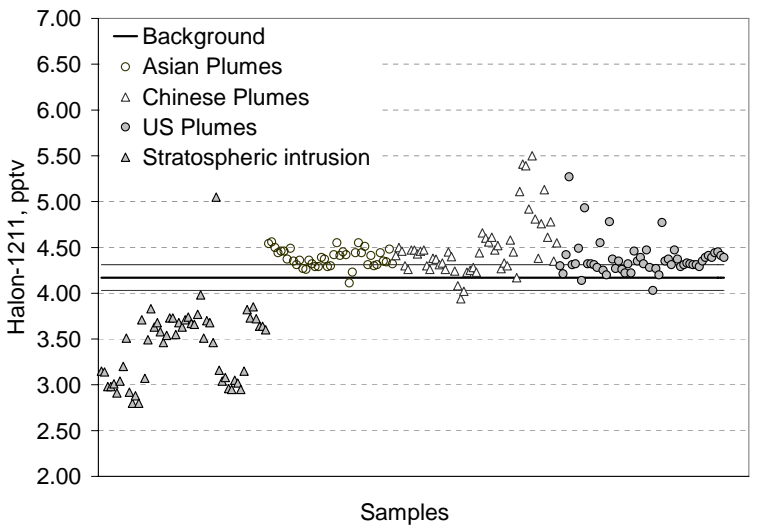

Fig. 7. Halon-1211 mixing ratios measured in the different pollution plumes identified. The 2- $\sigma$ SD calculated for the background is reported by the thin black lines above and below the thick background line.

of correlation was observed for all the other pollution plumes

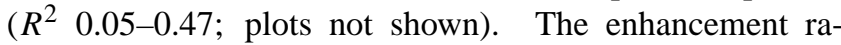
tios of OCS to $\mathrm{CO}$ for the five Chinese plumes range from 0.81 to $1.11 \mathrm{pptv} / \mathrm{ppbv}$ - in the high range of the Blake et al. (2004) observations of Chinese plumes - suggesting the detection of a large coal/biofuel combustion source located in China. For the other Asian plumes, the enhanced OCS mixing ratio without correlation between OCS and CO (or ethyne, $R^{2}<0.53$ ) indicates the presence of additional, noncombustion sources of OCS.

High mixing ratios of 1,2-dichloroethane (1,2-DCE) and ethyl chloride were measured in all of the pollution plumes, highlighting the anthropogenic origin of these compounds. $1,2-\mathrm{DCE}$ is used primarily as a chemical intermediate in the synthesis of other compounds (mainly vinyl chloride) or as a solvent (EPA, 1984), and is a leaded gasoline additive that is added on a mole-to-mole basis with lead (Clark et al., 1984). 1,2-Dichloroethane emissions from coal burning have also been suggested. Concentrations up to $3.51 \mu \mathrm{g} \mathrm{m}^{-3}$ (about 900 pptv) were measured in the gas phase of Spanish coal power station operations (Fernandez-Martinez et al., 2001). Ethylene chloride was extensively used in the production of tetraethyl lead (anti-knock additive for leaded gasoline) and it is now mostly used as blowing agent for foam plastics, solvent, refrigerant, and chemical intermediate (EPA, 2009).

The lowest average levels for both 1,2-DCE and ethyl chloride were observed in the US plumes ( $12 \pm 1$ to $14 \pm 0.8 \mathrm{pptv}$ for 1,2 -DCE; $5.0 \pm 0.7$ to $8.1 \pm 1.8$ pptv for ethyl chloride), followed by the Asian plumes ( $15 \pm 3$ to $21 \pm 8$ pptv for 1,2-DCE; $5.8 \pm 0.7$ to $8.9 \pm 1.6 \mathrm{pptv}$ for ethyl chloride), while the highest mixing ratios were measured in the Chinese air masses. Plumes \#4 and \#5 were particularly enhanced in 1,2-DCE, averaging $120 \pm 23 \mathrm{pptv}$ in plume \#4 (97-162 pptv range) and $80 \pm 36$ pptv average in plume \#5 

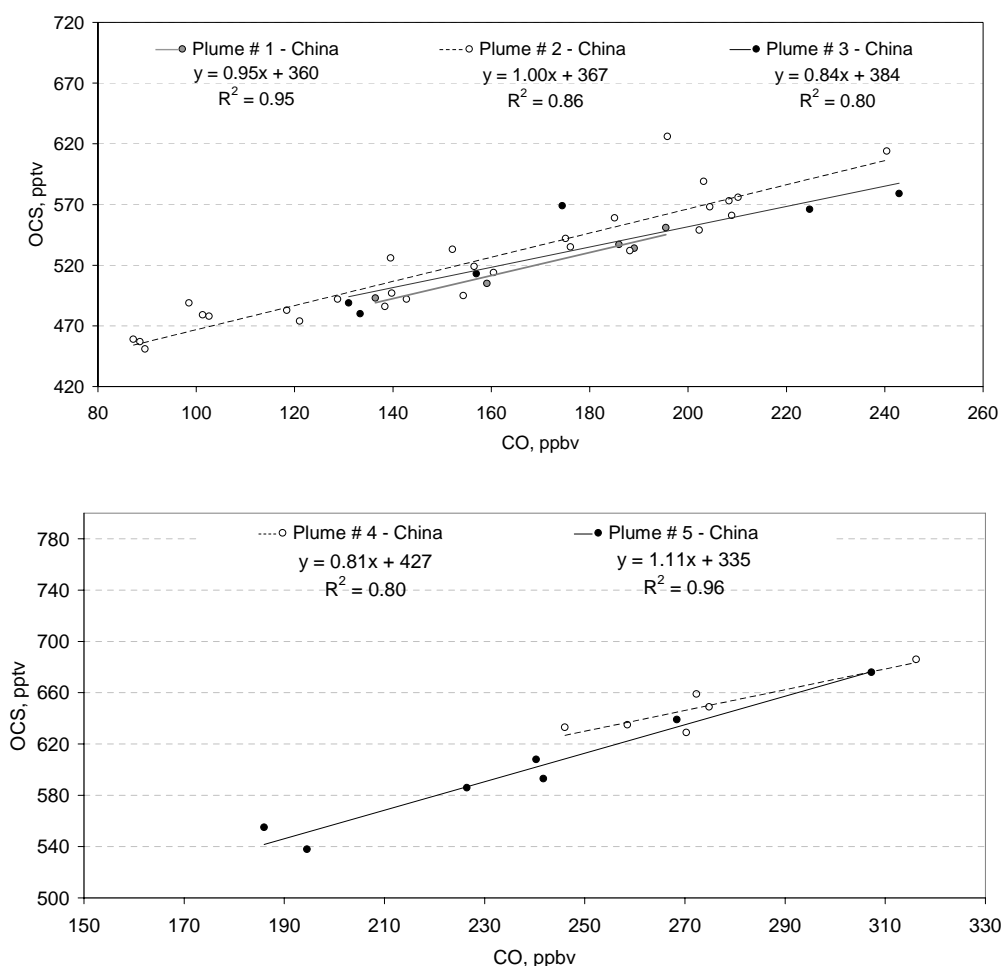

Fig. 8. Correlation plots of OCS verses CO for the five Chinese plumes identified during INTEX-B.

(46-147 pptv range). The highest levels of ethyl chloride were also observed in plume \#4 (29.7 \pm 7.9 pptv average; 21.4-44.0 pptv range) and plume \#5 (23.1 \pm 8.6 pptv average; 13.0-37.4 pptv range). The excellent correlation found between these two chlorinated compounds and the combustion tracer ethyne, the industrial solvent $\mathrm{CH}_{2} \mathrm{Cl}_{2}$, and the two coal/biomass burning tracers, OCS and $\mathrm{CH}_{3} \mathrm{Cl}$ (Table 5) was most likely because of co-located emission sources of these species in China. The high levels observed in the Chinese plumes, and good correlations with Chinese emitted NMHCs suggest the use of 1,2-DCE and ethyl chloride, in combination with other species, as a tracer of Chinese air masses.

\subsection{Principal component analysis (PCA)}

The discussion in the above sections was based on our segregation of pollution plume samples based on the enhancement of selected VOCs, while the geographical source of these pollution plumes was identified using the backward trajectories. Using the PCA analysis (briefly described below) we can identify the main underlying variables that explain most of the observed variance of the data set and through the analysis of the factor loadings we can determine the more representative species in each factor. Because the data set used in PCA must contain a large number of samples (no less than 50; Thurston and Spengler, 1985) the PCA was applied to the all the samples collected during INTEX-B (stratospheric intrusion excluded), to the plumes from China and, separately, from the US, whereas the pollution plumes from Asia only included 41 samples.

Briefly, the PCA is a mathematical algorithm widely used in atmospheric sciences that identifies a new set of uncorrelated and orthogonal variables (called factors or principal components - PCs) which are a linear combination of the original variables. The variance in all the variables accounted by a specific PC is measured by its eigenvalue, where the first PC identified accounts for most of the variance in the data; the second PC explains the maximum proportion of the remaining variance and it is uncorrelated with the first PC, and so on. Although the number of PCs is the same as the original variables, only the first few PCs are retained because they explain most of the total variance, and in our study only factors with an eigenvalue $>1$ were retained ("Kaiser criterion" of dropping the least important components; Kaiser, 1960). Principal component analysis starts with a data matrix of the original data, where samples are represented by $k$ rows and variables by $i$ columns, which is first standardized so that each variable has the same mean $(0)$ and standard deviation (1). To facilitate the interpretation of the PCA output, rotation methods for the retained components are needed and the varimax rotation, which is among the most popular rotation methods, is used here. Varimax rotation searches for a linear combination (i.e. orthogonal rotation) of the retained 
Table 5. Coefficient of determination and slope calculated for 1,2-dichloroethane and ethyl chloride versus ethyne, $\mathrm{C}_{2} \mathrm{HCl}_{3}, \mathrm{OCS}$, and $\mathrm{CH}_{3} \mathrm{Cl} . \mathrm{NC}=$ No Correlation $\left(R^{2}<0.50\right)$.

\begin{tabular}{|c|c|c|c|c|}
\hline & \multicolumn{4}{|c|}{ 1,2-Dichloroethane vs.: } \\
\hline & Ethyne $R^{2}$ (slope) & $\mathrm{C}_{2} \mathrm{HCl}_{3} R^{2}$ (slope) & OCS $R^{2}$ (slope) & $\mathrm{CH}_{3} \mathrm{Cl} R^{2}$ (slope) \\
\hline Plume \# 1 & $0.83(0.06)$ & $0.97(8.5)$ & $0.89(0.29)$ & $0.82(0.24)$ \\
\hline Plume \# 2 & $0.93(0.07)$ & $0.89(32)$ & $0.85(0.22)$ & $0.77(0.31)$ \\
\hline Plume \# 3 & $0.98(0.06)$ & $0.64(52)$ & $0.96(0.22)$ & $0.64(0.28)$ \\
\hline Plume \# 4 & $0.93(0.20)$ & $\mathrm{NC}$ & $0.93(1.05)$ & $0.82(0.70)$ \\
\hline \multirow[t]{3}{*}{ Plume \# 5} & $0.95(0.18)$ & $0.97(32)$ & $0.90(0.72)$ & $0.99(0.69)$ \\
\hline & \multicolumn{4}{|c|}{ Ethyl chloride vs.: } \\
\hline & Ethyne $R^{2}$ (slope) & $\mathrm{C}_{2} \mathrm{HCl}_{3} R^{2}$ (slope) & OCS $R^{2}$ (slope) & $\mathrm{CH}_{3} \mathrm{Cl} R^{2}$ (slope) \\
\hline Plume \# 1 & $0.85(0.02)$ & $0.97(3.3)$ & $0.91(0.11)$ & $0.88(0.09)$ \\
\hline Plume \# 2 & $0.90(0.02)$ & $0.83(8.4)$ & $0.82(0.06)$ & $0.80(0.09)$ \\
\hline Plume \# 3 & $0.99(0.01)$ & $0.52(10.9)$ & $0.99(0.05)$ & $0.74(0.07)$ \\
\hline Plume \# 4 & $0.71(0.06)$ & $\mathrm{NC}$ & $0.70(0.31)$ & $0.56(0.19)$ \\
\hline Plume \# 5 & $0.98(0.04)$ & $0.91(7.4)$ & $0.96(0.18)$ & $0.95(0.16)$ \\
\hline
\end{tabular}

factors so that the variance of the loadings is maximized, and each original variable is then associated with only a smaller number of factors. To obtain the PCs, the PC's eigenvalues, and the component loadings, we used MATLAB statistical software package (the Mathworks Inc., Natick, MA). Choi et al. (2003) showed that stable results cab be obtained with an excess of about 25 samples (i.e. $k>i+25$ ). Mixing ratios lower than the limits of detection are indicated as zero in the original data set (censored values). Considering the limited number of samples representing the pollution plumes, two main arbitrary decisions were made. First, when the number of zeros was more than $10 \%$ of the number of samples in each pollution plume, the species was removed from the data set. When less than $10 \%$ of zeros were present, they were substituted by one half of the detection limit. This decision made to keep the highest possible number of data points in the PCA process. The expected bias in the PCA result should be minimal because of the very few number of censored values. For instance, only two mixing ratios were lower than the detection limit in the data matrix of US plumes (both for $\mathrm{CS}_{2}$ ), and five in the Chinese plumes data matrix ( 3 for $i$-butane, 1 for $n$-butane, and 2 for benzene). Second, to limit the number of variables in the original data matrix of the Chinese and US pollution plumes, we decided to remove two CFCs (CFC-113, and CFC-114) and two HCFCs (HCFC-141b and HCFC-142b). These VOCs were selected after considering that their emission signature can be represented by the other CFCs and CFC replacements retained in the data matrix (the list of trace gases included in the PCA for the Chinese and US plumes are reported in Tables 7 and 8). Because of the high number of samples included in the INTEX-B data set $(2387$ canisters), we were able to eliminate all censored value, and still have enough samples for the PCA $(k=1321$ in the final INTEX-B data matrix).
The association of the different species with a specific source (or sources) was based on general knowledge of global VOC sources. The reader is referred to Choi et al., 2003 (and references therein) and Tyler et al., 2007 for $\mathrm{CH}_{4}$, $\mathrm{C}_{2}-\mathrm{C}_{5}$ hydrocarbons, and aromatic compounds sources; to Blake et al., 2004 for OCS and $\mathrm{CS}_{2}$ sources; to Fraser et al., 1999 for Halon's sources; to McCulloch et al., 2001, 2003 for CFCs and CFC replacements sources; to Simpson et al., 2004 for $\mathrm{C}_{2} \mathrm{Cl}_{4}$ sources, and Trudinger et al., 2004 for the remaining halogenated compounds sources.

Six PCs were retained for the INTEX-B data set. Table 6 shows the factor loadings of the three major PCs together representing $\sim 60 \%$ of the variance. The first PC accounted for more than one third of the variance $(38 \%)$ and showed high loadings $(>0.70)$ of halogenated solvents $\left(\mathrm{CHCl}_{3}, \mathrm{CH}_{2} \mathrm{Cl}_{2}\right.$, ethyl chloride, and 1,2-DCE), and combustion products (ethyne, benzene, and OCS). These trace gases reflected the influence of industrial and fuel combustion sources suggesting the impact of anthropogenic activities in the INTEX-B air masses and, because of the high loading in OCS (and to a lesser extent $\mathrm{CH}_{3} \mathrm{Cl}$ ), by biofuel/coal burning in particular. The second and third PCs each accounted for about $12 \%$ of the overall remaining variance, with noticeably high loadings in the butanes and $i$-pentane for PC2 and CFCs for PC-3. Therefore, it appeared that liquefied petroleum gas (LPG) usage (suggested by the high loadings of the butanes) and gasoline evaporations (indicated by $i$ pentane) were the dominant sources in the second PC. The high factor loadings highlighted in the third PC suggested the presence of a CFC related source, which, however, accounts for only $12 \%$ of the variance.

Three PCs were retained for the Chinese plumes data set (Table 7). The first PC accounted for about $70 \%$ of the overall variance and was dominated by a combustion signature 
Table 6. Factor loading of the three major principal components with an eigenvalue $>1$ calculated for the INTEX-B data set using PCA. Only loadings higher than 0.30 are reported.

\begin{tabular}{|c|c|c|c|}
\hline & PC-1 & PC-2 & PC-3 \\
\hline OCS & 0.71 & & \\
\hline $\mathrm{CS} 2$ & 0.32 & & \\
\hline CFC-12 & & & 0.61 \\
\hline CFC-11 & & & 0.85 \\
\hline CFC-113 & & & 0.86 \\
\hline CFC-114 & & & 0.69 \\
\hline Halon-1211 & 0.53 & & 0.44 \\
\hline Halon-2402 & & & 0.74 \\
\hline Halon-1301 & & & 0.38 \\
\hline HFC-134a & & 0.47 & \\
\hline HCFC-22 & 0.46 & 0.33 & 0.32 \\
\hline HCFC-142b & 0.48 & 0.32 & \\
\hline HCFC-141b & 0.65 & & \\
\hline $\mathrm{CHCl}_{3}$ & 0.90 & & \\
\hline $\mathrm{CCl}_{4}$ & 0.34 & & 0.60 \\
\hline $\mathrm{CH}_{2} \mathrm{Cl}_{2}$ & 0.88 & & \\
\hline $\mathrm{C}_{2} \mathrm{HCl}_{3}$ & 0.62 & 0.38 & \\
\hline $\mathrm{C}_{2} \mathrm{Cl}_{4}$ & 0.42 & 0.56 & \\
\hline $\mathrm{CH}_{3} \mathrm{Cl}$ & 0.57 & & \\
\hline \multicolumn{4}{|l|}{$\mathrm{CH}_{3} \mathrm{Br}$} \\
\hline $\mathrm{CH}_{3} \mathrm{I}$ & & & 0.33 \\
\hline $\mathrm{CHBr}_{3}$ & & & 0.32 \\
\hline Ethyl chloride & 0.92 & & \\
\hline 1,2-DCE & 0.95 & & \\
\hline Ethane & 0.35 & 0.43 & \\
\hline Ethyne & 0.78 & & \\
\hline Propane & & 0.59 & \\
\hline$i$-Butane & & 0.89 & \\
\hline$n$-Butane & & 0.96 & \\
\hline$i$-Pentane & & 0.89 & \\
\hline Benzene & 0.82 & 0.31 & \\
\hline Eigenvalue & 11.8 & 3.9 & 3.6 \\
\hline$\%$ of Variance & 37.9 & 12.5 & 11.7 \\
\hline Cumulative $\%$ & 37.9 & 50.4 & 62.1 \\
\hline
\end{tabular}

with high loadings $(>0.9)$ of the general combustion products ethyne and benzene, and of the biomass/coal burning tracers $\mathrm{OCS}$ and $\mathrm{CH}_{3} \mathrm{Cl}$. Following the analysis of Sect. 3.3, we attributed the high loading of 1,2-DCE and ethyl chloride (0.95) to the presence of particularly strong emission sources (not clearly identified) in China. Factor 1 also reflected the presence of an urban/industrial signature with high loadings $(>0.90)$ for industrial solvents $\left(\mathrm{CH}_{2} \mathrm{Cl}_{2}\right.$, $\mathrm{C}_{2} \mathrm{HCl}_{3}$ and $\mathrm{CHCl}_{3}$ ), CFC replacements, Halon-1211, and urban tracer $\mathrm{C}_{2} \mathrm{Cl}_{4}$. Factor 2 was similar to the second $\mathrm{PC}$ of the INTEX-B data with high loadings for the CFCs, while factor 3 had very low factor loadings of ethyne and benzene $(<0.30)$ indicating its insignificant relation to combustion sources. In contrast, high factor loadings of propane and the butanes in PC-3 suggest the presence of LPG usage, al-
Table 7. Factor loading of principal components with an eigenvalue $>1$ calculated for INTEX-B Chinese pollution plumes using PCA. Only loadings higher than 0.30 are reported.

\begin{tabular}{|c|c|c|c|}
\hline & PC-1 & PC-2 & PC-3 \\
\hline OCS & 0.88 & & \\
\hline $\mathrm{CS} 2$ & 0.62 & 0.39 & \\
\hline CFC-12 & & 0.78 & \\
\hline CFC-11 & & 0.87 & \\
\hline Halon-1211 & 0.86 & & \\
\hline Halon-2402 & & 0.82 & \\
\hline Halon-1301 & & 0.67 & \\
\hline HFC-134a & 0.74 & 0.44 & \\
\hline HCFC-22 & 0.90 & & \\
\hline $\mathrm{CHCl}_{3}$ & 0.95 & & \\
\hline $\mathrm{CCl}_{4}$ & 0.66 & 0.57 & \\
\hline $\mathrm{CH}_{2} \mathrm{Cl}_{2}$ & 0.94 & & \\
\hline $\mathrm{C}_{2} \mathrm{HCl}_{3}$ & 0.90 & & 0.31 \\
\hline $\mathrm{C}_{2} \mathrm{Cl}_{4}$ & 0.90 & & 0.33 \\
\hline $\mathrm{CH}_{3} \mathrm{Cl}$ & 0.94 & & \\
\hline $\mathrm{CH}_{3} \mathrm{Br}$ & 0.86 & & \\
\hline $\mathrm{CH}_{3} \mathrm{I}$ & 0.83 & & 0.34 \\
\hline $\mathrm{CHBr}_{3}$ & & 0.43 & \\
\hline Ethyl chloride & 0.95 & & \\
\hline 1,2-DCE & 0.95 & & \\
\hline Ethane & 0.73 & & 0.59 \\
\hline Ethyne & 0.93 & & \\
\hline Propane & 0.70 & & 0.65 \\
\hline$i$-Butane & 0.71 & & 0.67 \\
\hline$n$-Butane & 0.50 & & 0.83 \\
\hline Benzene & 0.92 & & \\
\hline Eigenvalue & 18.7 & 2.9 & 1.2 \\
\hline$\%$ of Variance & 71.9 & 11.1 & 4.5 \\
\hline Cumulative $\%$ & 71.9 & 83.0 & 87.5 \\
\hline
\end{tabular}

though this source only accounts for less than $5 \%$ of the variance. The CFC high factor loadings calculated in the second PC suggested the presence of a CFC related source in the Chinese air masse, but no enhancement of CFCs in the Chinese air masses was observed. The dilution of the polluted air masses along the transport between the emission source and the sampling point can possibly explain the lack of CFC enhancement in the Chinese plumes, although we point out that the CFC related source in the Chinese air masses (as highlighted by the PCA) only accounted for $\sim 11 \%$ of the variance.

Seven PCs were retained for the US plumes data set. The three main PCs together representing $64 \%$ of the variance are shown in Table 8; while the remaining four minor PCs each represented $\sim 4-6 \%$ of the variance. The first factor (explaining $43 \%$ of the total variance) was dominated by combustion tracers (ethyne, benzene and toluene) and urban/industrial pollutants $\left(\mathrm{C}_{2} \mathrm{Cl}_{4}\right.$ in particular). However, a clear difference was observed compared to the Chinese plumes, with very low loadings of Halon-1211 and the biomass/coal burning tracers $\mathrm{CH}_{3} \mathrm{Cl}$ and OCS $(<0.30)$. High factor loadings of the butanes and pentanes were also found 
in the first factor pointing out to LPG and gasoline evaporation related sources. Factor 2 indicated marine influence with high loading of the methyl iodide $\left(\mathrm{CH}_{3} \mathrm{I}\right)$ and bromoform $\left(\mathrm{CHBr}_{3}\right)$ but also anthropogenic influence because of the high loadings of chlorinated solvents $\left(\mathrm{CHCl}_{3}\right.$ and ethyl chloride). Finally, the high factor loadings of $\mathrm{OCS}$ and $\mathrm{CH}_{3} \mathrm{Cl}$ in factor 3 suggested some impact from biomass/coal burning. However, this PC only accounted for less than $10 \%$ of the variance.

\section{Conclusions}

We were able to identify 12 pollution plumes encountered during INTEX-B: five plumes originated from China, four plumes from other Asian countries, and three plumes from the United States. Four of the five Chinese plumes were sampled far away from the source region, close to the west coast of the United States or inland over the North American continent. This highlights the efficient transport of Asian air masses across the Pacific region during spring. These pollution plumes showed a higher ethyne/CO ratio with respect to the rest of the samples collected during INTEX-B and the stratospherically influenced plume, highlighting the recent impact of recently polluted air masses. The background levels calculated during INTEX-B were overall consistent with the INTEX-A background mixing ratios. Higher levels were observed in 2006 (INTEX-B) for a few gases (namely OCS, HFC-134a, HCFC-142b, methylene chloride, methyl chloride, 1,2-dichloroethane, ethane, and ethyne).

The VOC enhancement with respect to the regional background in the different pollution plumes reflected the presence of different sources. In particular, the correlation analysis of OCS versus CO confirmed the importance of coal burning as a specific source for OCS (as opposed to biomass burning). Elevated mixing ratios of CFC replacements were measured in all of the US plumes, and in selected Chinese plumes. HFC-134a was particularly enhanced in air masses influence by US emissions. The Chinese plumes were highly enhanced in OCS, $\mathrm{CH}_{3} \mathrm{Cl}, 1$,2-dichloroethane, ethyl chloride, and Halon-1211. We suggest the use of this combination of gases as specific tracers for the identification of Chinese air masses as opposed to the use of a single species such as Halon-1211. We anticipate that Halon-1211 will slowly decrease its role as a "specific" Chinese tracer as suggested by the relatively low levels measured in some of the Chinese plumes encountered during INTEX-B. Finally, the PCA provided an additional tool to evaluate the main sources affecting the VOC levels in the whole INTEX-B data set and in the specific pollution plumes. The impact of urban emissions in the samples collected during the airborne mission was indicated by the high loadings of trace gases associated with strong anthropogenic sources. The analysis of the major
Table 8. Factor loading of the three major principal components with an eigenvalue $>1$ calculated for INTEX-B US pollution plumes using PCA. Only loadings higher than 0.30 are reported.

\begin{tabular}{|c|c|c|c|}
\hline & PC-1 & PC-2 & PC-3 \\
\hline OCS & & & 0.74 \\
\hline \multicolumn{4}{|l|}{ CS2 } \\
\hline CFC-12 & & & 0.68 \\
\hline \multicolumn{4}{|l|}{ CFC-11 } \\
\hline \multicolumn{4}{|l|}{ Halon-1211 } \\
\hline \multicolumn{4}{|l|}{ Halon-2402 } \\
\hline \multicolumn{4}{|l|}{ Halon-1301 } \\
\hline HFC-134a & 0.65 & 0.57 & 0.35 \\
\hline HCFC-22 & 0.63 & 0.39 & 0.59 \\
\hline \multirow{2}{*}{\multicolumn{4}{|c|}{$\mathrm{CCl}_{4}$}} \\
\hline & & & \\
\hline $\mathrm{CH}_{2} \mathrm{Cl}_{2}$ & 0.65 & 0.55 & \\
\hline $\mathrm{C}_{2} \mathrm{HCl}_{3}$ & 0.61 & & \\
\hline $\mathrm{C}_{2} \mathrm{Cl}_{4}$ & 0.87 & & \\
\hline $\mathrm{CH}_{3} \mathrm{Cl}$ & & & 0.75 \\
\hline \multicolumn{4}{|l|}{$\mathrm{CH}_{3} \mathrm{Br}$} \\
\hline $\mathrm{CH}_{3} \mathrm{I}$ & & 0.73 & \\
\hline $\mathrm{CHBr}_{3}$ & 0.53 & 0.66 & \\
\hline Ethyl chloride & & 0.61 & \\
\hline 1,2-DCE & & & 0.40 \\
\hline \multicolumn{4}{|l|}{ Ethane } \\
\hline Ethene & 0.64 & & \\
\hline Ethyne & 0.76 & & \\
\hline Propane & 0.53 & 0.31 & \\
\hline$i$-Butane & 0.84 & & \\
\hline$n$-Butane & 0.91 & & \\
\hline$i$-Pentane & 0.92 & 0.32 & \\
\hline$n$-Pentane & 0.88 & & \\
\hline Benzene & 0.86 & & \\
\hline Toluene & 0.94 & & \\
\hline Eigenvalue & 12.9 & 3.5 & 2.8 \\
\hline$\%$ of Variance & 43.1 & 11.5 & 9.4 \\
\hline Cumulative \% & 43.1 & 54.6 & 64.0 \\
\hline
\end{tabular}

PCs extracted for the Chinese air samples and US air masses pointed to the presence of sources consistent with Chinese and North American influence. In particular, the main principal component extracted for the Chinese data matrix (accounting for $\sim 70 \%$ of the variance) showed high loadings of many anthropogenic emitted trace gases including the Chinese tracers suggested by the VOC data analysis (namely OCS, $\mathrm{CH}_{3} \mathrm{Cl}$, 1,2-dichloroethane, ethyl chloride, and Halon1211).

Acknowledgements. The authors would like to thank the flight crew of the NASA DC-8 and NSF/NCAR C-130 aircraft for their help during the field deployment, and B. Love and G. Liu (University 
of California, Irvine) for technical support. We also would like to thank the reviewers for their valuable comments. This work was funded by the NASA Global Tropospheric Chemistry Program.

Edited by: H. Singh

\section{References}

Atkinson, R.: Atmospheric chemistry of VOCs and $\mathrm{NO}_{\mathrm{x}}$, Atmos. Environ., 34, 2063-2101, 2000.

Barnes, D. H., Wofsy, S. C., Fehlau, B. P., Gottlieb, E. W., Elkins, J. W., Dutton, G. S., and Montzka, S. S.: Urban/Industrial pollution for the New York City - Washington, DC, corridor, 19961998: 2. A study of the efficacy of the Montreal Protocol and other regulatory measures, J. Geophys. Res., 108(D6), 4186, doi:10.1029/2001JD001117, 2003.

Bell, M. L., McDermott, A., Zeger, S. L., Samet, J. M., and Dominici, F.: Ozone and short-term mortality in 95 US urban communities, 1987-2000, J. Amer. Med. Assoc., 292(19), 23722378, 2004.

Berntsen, T. K., Isaksen, I. S. A., Myhre, G., Fuglestvedt, J. S., Stordal, F., Larsen, T. A., Freckleton, R. S., and Shine, K. P.: Effects of anthropogenic emissions on tropospheric ozone and its radiative forcing, J. Geophys. Res., 102(D23), 28,101-28,126, 1997.

Blake, N. J., Streets, D. G., Woo, J.-H., Simpson, I. J., Green, J., Meinardi, S., Kita, K., Atlas, E., Fuelberg, H. E., Sachse, G., Avery, M. A., Vay, S. A., Talbot, R. W., Dibb, J. E., Bandy, A. R., Thornton, D. C., Rowland, F. S., and Blake, D. R.: Carbonyl sulfide and carbon disulfide : large-scale distributions over the western Pacific and emissions form Asia during TRACE P, J. Geophys. Res., 109, D15S05, doi:10.1029/2003JD004259, 2004.

Blake, N. J., Blake, D. R., Simpson, I. J., Meinardi, S., Swanson, A. L., Lopez, J. P., Katzenstein, A. S., Barletta, B., Shirai, T., Atlas, E., Sachse, G., Avery, M., Vay, S., Fuelberg, H. E., Kiley, C. M., Kita, K., and Rowland, F. S.: NMHCs and halocarbons in Asian continental outflow during the transport and chemical evolution over the Pacific (TRACE - P) field campaign: comparison with PEM-West B, J. Geophys. Res., 108(D20), 8806, doi:10.1029/2002JD003367, 2003.

Chin, M. and Davis, D. D.: Global sources and sinks of carbonyl sulfide and carbon disulfide and their distributions, Global Biogeochem. Cy., 7(2), 321-37, 1993.

Choi, Y., Elliott, S., Simpson, I. J., Blake, D. R., Colman, J. J., Dubey, M. K., Meinardi, S., Rowland, F. S., Shirai, T., and Smith, F. A.: Survey of whole air data from the second airborne biomass burning and lightning experiment using principal component analysis, J. Geophys. Res., 108(D5), ACH3/1-ACH3/10, doi:10.1029/2002JD002841, 2003.

Clark, A. I., McIntyre, A. E., Perry, R., and Lester, J. N.: Monitoring and assessment of ambient atmospheric concentrations of aromatic and halogenated hydrocarbons at urban, rural and motorway locations, Environ. Pollut. B, 7, 141-158, 1984.

Colman, J. J., Swanson, A. L., Meinardi, S., Sive, B. C., Blake, D. R., and Rowland, F. S.: Description of the analysis of a wide range of volatile organic compounds in whole air samples col- lected during PEM-Tropics A and B, Anal. Chem., 73, 37233731, 2001.

de Gouw, J. A., Middlebrook, A. M., Warneke, C., Goldan, P. D., Kuster, W. C., Roberts, J. M., Fehsenfeld, F. C., Worsnop, D. R., Canagaratna, M. R., Pszenny, A. A. P., Keene, W. C., Marchewka, M., Bertman, S. B., and Bates, T. S.: Budget of organic carbon in a polluted atmosphere: Results from the New England Air Quality Study in 2002, J. Geophys. Res., 110, D16305, doi:10.1029/2004JD005623, 2005.

Ehhalt, D. H., Rohrer, F., Wahner, A., Prather, M. J., and Blake, D. R.: On the use of hydrocarbons for the determination of tropospheric OH concentrations, J. Geophys. Res., 103(D15), 18,98118,997, 1998.

Energy Information Administration (EIA), International energy annual 2006, http://www.eia.doe.gov/emeu/iea/coal.html, access: June 2009.

Environmental Protection Agency (EPA): Locating and estimating air emissions from sources of ethylene dichloride, EPA-450/484-007d, March 1984, 1984.

Environmental Protection Agency (EPA); http://www.epa.gov/ttn/ atw/hlthef/chloroet.html, access: May 2009.

Fernandez-Martinez, G., Lopez-Mahia, P., Muniategui-Lorenzo, S., Prada-Rodriguez, D., and Fernandez-Fernandez, E.: Distribution of volatile organic compounds during the combustion process in coal - fired power stations, Atmos. Environ., 35(33), 5823-5831, 2001.

Forster, C., Cooper, O., Stohl, A., Eckhardt, S., James, P., Dunlea, E., Nicks Jr., D. K., Holloway, J. S., Hübler, G., Parrish, D. D., Ryerson, T. B., and Trainer, M.: Lagrangian transport model forecasts and a transport climatology for the Intercontinental Transport and Chemical Transformation 2002 (ITCT 2K2) measurement campaign, J. Geophys. Res., 109, D07S92, doi:10.1029/2003JD003589, 2004.

Fraser, P. J., Oram, D. E., Reeves, C. E., Penkett, S. A., and McCulloch, A.: Southern hemispheric halon trends (1978-1998) and global halon emissions, J. Geophys. Res., 104(D13), 1598515999, 1999.

Gerbig, C., Schmitgen, S., Kley, D., Volz-Thomas, A., Dewey, K., and Haaks, D.: An improved fast-response vacuum-UV resonance fluorescence CO instrument, J. Geophys. Res., 104(D1), 1699-1704, 1999.

Heard, D.E., and Pilling, M.J.: Measurement of $\mathrm{OH}$ and $\mathrm{HO}_{2}$ in the Troposphere, Chem. Rev., Washington, DC, USA, 103(12), 5163-5198, 2003.

Holzer, M., Hall, T. M., and Stull, R. B.: Seasonality and weatherdriven variability of transpacific transport, J. Geophys. Res., 110, D23103, doi:10.1029/2005JD006261, 2005.

Hurst, D. F., Lin, J. C., Romashkin, P. A., Daube, B. C., Gerbig, C., Matross, D. M., Wofsy, S. C., Hall, B. D., and Elkins, J. W.: Continuing global significance of emissions of Montreal Protocolrestricted halocarbons in the United States and Canada, J. Geophys. Res., 111(D15302), doi:10.1029/2005JD006785, 2006.

IPCC; Climate Change 2007: The Physical Science Basis; Working group I Contribution to the Fourth Assessment Report of the Intergovernmental Panel on Climate Change; Cambridge University Press: New York, USA, 2007.

Jacob, D. J., Crawford, J. H., Kleb, M. M., Connors, V. S., Bendura, R. J., Raper, J. L., Sachse, G. W., Gille, J. C., Emmons, L., and Heald, C. L.: Transport and Chemical Evolution over the Pacific 
(TRACE-P) aircraft mission: Design, execution, and first results, J. Geophys. Res., 108(D20), 9000, doi:10.1029/2002JD003276, 2003.

Jaffe, D., Anderson, T., Covert, D., Trost, B., Danielson, J., Simpson, W., Blake, D., Harris, J., and Streets, D.: Observations of ozone and related species in the northeast Pacific during the PHOBEA campaigns 1. Ground-based observations at Cheeka Peak, J. Geophys. Res., 106(D7), 7449-7461, 2001.

Junge, C. E.: Residence time and variability of tropospheric trace gases, Tellus, 26(4), 477-88, 1974.

Kaiser, H. F.: The application of electronic computers to factor analysis, Educ. Psychol. Meas., 20, 141-51, 1960.

Khalil, M. A. K., and Rasmussen, R. A.: Global sources, lifetimes and mass balances of carbonyl sulfide (OCS) and carbon disulfide (CS2) in the earth's atmosphere, Atmos. Environ., 18, 18051813, 1984.

Khalil, M. A. K. and Rasmussen, R. A.: Atmospheric methyl chloride, Atmos. Environ., 33(8), 1305-1321, 1999.

Lelieveld, J., Berresheim, H., Borrmann, S., Crutzen, P. J., Dentener, F. J., Fischer, H., Feichter, J., Flatau, P. J., Heland, J., Holzinger, R., Korrmann, R., Lawrence, M. G., Levin, Z., Markowicz, K. M., Mihalopoulos, N., Minikin, A., Ramanathan, V., de Reus, M., Roelofs, G. J., Scheeren, H. A., Sciare, J., Schlager, H., Schultz, M., Siegmund, P., Steil, B., Stephanou, E. G., Stier, P., Traub, M., Warneke, C., Williams, J., and Ziereis, H.: Global Air Pollution Crossroads over the Mediterranean, Washington, DC, USA, Science, 298(5594), 794-799, 2002.

Liang, Q., Jaegle, L., Hudman, R. C., Turquety, S., Jacob, D. J., Avery, M. A., Browell, E. V., Sachse, G. W., Blake, D. R., Brune, W., Ren, X., Cohen, R. C., Dibb, J. E., Fried, A., Fuelberg, H., Porter, M., Heikes, B. G., Huey, G., Singh, H. B., and Wennberg, P. O.: Summertime influence of Asian pollution in the free troposphere over North America, J. Geophys. Res., 112, D12S11, doi:10.1029/2006JD007919, 2007.

Liang, Q., Jaegle, L., Jaffe, D. A., Weiss-Penzias, P., Heckman, A., Snow, J. A.: Longrange transport of Asian pollution to the northeast Pacific: Seasonal variations and transport pathways of carbon monoxide, J. Geophys. Res., 109, D23S07, doi:10.1029/2003JD004402, 2004.

Liu, H., Jacob, D. J., Bey, I., Yantosca, R. M., Duncan, B. N., and Sachse, G. W.: Transport pathways for Asian pollution outflow over the Pacific: Interannual and seasonal variations, J. Geophys. Res., 108(D20), 8786, doi:10.1029/2002JD003102, 2003.

Liu, H., Jacob, D. J., Chan, L. Y., Oltmans, S. J., Bey, I., Yantosca, R. M., Harris, J. M., Duncan, B. N., and Martin, R. V.: Sources of tropospheric ozone along the Asian Pacific rim: An analysis of ozonesonde observations, J. Geophys. Res., 107(D21),4573, doi:10.1029/2001JD002005, 2002.

Logan, J. A., Prather, M. J., Wofsy, S. C., and McElroy, M. B.: Tropospheric chemistry: a global prospective, J. Geophys. Res., 86, 7210-7254, 1981.

McCulloch, A., Ashford, P., Midgley, P. M.: Historic emissions of fluorotrichloromethane (CFC-11) based on a market survey, Atmos. Environ., 35(26), 4387-4397, 2001.

McCulloch, A., Midgley, P. M., and Ashford, P.: Releases of refrigerant gases (CFC-23, HCFC-22 and HFC-134a) to the atmosphere, Atmos. Environ., 37(7), 889-902, 2003.

McKeen, S., Liu, S., Hsie, E.-Y., Lin, X., Bradshaw, J., Smyth, S., Gregory, G., and Blake, D.: Hydrocarbon ratios during PEM-
WEST A: A model perspective, J. Geophys. Res., 101(D1), 2087-2109, 1996.

McKeen, S. A. and Liu, S. C.: Hydrocarbon ratios and photochemical history of air masses, Geophys. Res. Lett., 20, 2363-2366, 1993.

Meinardi, S., Simpson, I. J., Blake, N. J., Blake, D. R., and Rowland, F. S.: Dimethyl disulfide (DMDS) and dimethyl sulfide (DMS) emissions from biomass burning in Australia, Geophys. Res. Lett., 30(9), 1454, doi:10.1029/2003GL016967, 2003.

Montzka, S. A., Butler, J. H., Hall, B. D., Mondeel, D. J., and Elkins, J. W.: A decline in tropospheric organic bromine, Geophys. Res. Lett., 30(15), 1826, doi:10.1029/2003GL017745, 2003.

Montzka, S. A., Calvert, P., Hall, B. D., Elkins, J. W., Conway, T. J., Tans, P. P., and Sweeney, C.: On the global distribution, seasonality, and budget of atmospheric carbonyl sulfide (COS) and some similarities to CO2, J. Geophys. Res, 112(D9), D09302/1D09302/15, doi:10.1029/2006JD007665, 2007.

NOAA/ESRL: National Oceanic and Atmospheric Administration (NOAA)/ Earth System Research Laboratory (ESRL), 2008, www.esrl.noaa.gov/gmd/hats/insitu/cats/cats_conc.html; access: August 2008.

NOAA/GMD: National Oceanic and Atmospheric Administration (NOAA)/Climate Monitoring Division (GMD); Boulder, CO; 2008; ftp://ftp.cmdl.noaa.gov/hats/halons/flaskst, access: August 2008.

Parrish, D. D., Hahn, C. J., Williams, E. J., Norton, R. B., Fehsenfeld, F. C., Singh, H. G., Shetter, J. D., Gandrud, B. W., and Ridley, B. A.: Indications of photochemical histories of Pacific air masses from measurements of atmospheric trace species at Point Arena, California, J. Geophys. Res., 97(D14), 15,883-15,901, 1992.

Parrish, D. D., Stohl, A., Forster, C., Atlas, E. L., Blake, D. R., Goldan, P. D., Kuster, W. C., and de Gouw, J. A.: Effects of mixing on evolution of hydrocarbon ratios in the troposphere, J. Geophys. Res., 112, D10S34, doi:10.1029/2006JD007583, 2007.

Pearson Jr., R. and Stedman, D. H.: Instrumentation for fast response ozone measurements from aircraft, Atmos. Technol., 12, 51-55, 1980.

Ridley, B., Ott, L., Pickering, L., Emmons, L., Montzka, D., Weinheimer, A., Knapp, D., Grahek, F., Li, L., Heymsfield, G., McGill, M., Kucera, P., Mahoney, M.J., Baumgardner, D., Schults, M., and Brasseur, G.: Florida thunderstorms: a faucet of reactive nitrogen to the upper troposphere, J. Geophys. Res., 109, D17305, doi:10.1029/2004JD004769, 2004.

Sachse, G., Hill, G., Wade, L., and Perry, M.: Fast-Response, HighPrecision Carbon Monoxide Sensor Using a Tunable Diode Laser Absorption Technique, J. Geophys. Res., 92(D2), 2071-2081, 1987.

Seinfeld, J. H.: Urban air pollution: state of the science, Science, 243(4892), 745-752, 1989.

Simpson, I. J., Blake, N. J., Blake, D. R., Atlas, E., Flocke, F., Crawford, J. H., Fuelberg, H. E., Kiley, C. M., Meinardi, S., Rowland, F. S.: Photochemical production and evolution of selected C2C5 alkyl nitrates in tropospheric air influenced by Asian outflow, J. Geophys. Res., 108(D20), 8808, doi:10.1029/2002JD002830, 2003.

Simpson, I. J., Meinardi, S., Blake, N. J., Rowland, F. S., and Blake, D. R.: Long-term decrease in the global atmospheric 
burden of tetrachloroethene (C2Cl4), Geophys. Res. Lett., 31(8), L08108/1-L08108/5, 2004.

Singh, H. B., Brune, W. H., Crawford, J. H., Flocke, F., and Jacob, D. J.: Chemistry and transport of pollution over the Gulf of Mexico and the Pacific: spring 2006 INTEX-B campaign overview and first results, Atmos. Chem. Phys., 9, 2301-2318, 2009, http://www.atmos-chem-phys.net/9/2301/2009/.

Stohl, A., Eckhardt, S., Forster, C., James, P., and Spichtinger, N.: On the pathways and timescales of intercontinental air pollution transport, J. Geophys. Res., 107(D23), 4684, doi:10.1029/2001JD001396, 2002.

Stohl, A., Hittenberger, M., and Wotawa, G.: Validation of the Lagrangian particle dispersion model FLEXPART against large scale tracer experiment data, Atmos. Environ., 24, 4245-4264, 1998.

Talbot, R., Dibb, J., Scheuer, E., Seid, G., Russo, R., Sandholm, S., Tan, D., Singh, H., Blake, D., Blake, N., Atlas, E., Sachse, G., Jordan, C., Avery, M.: Reactive nitrogen in Asian continental outflow over the western Pacific: results from the NASA transport and chemical evolution over the Pacific (TRACE-P) airborne mission, J. Geophys. Res, 108(D20), GTE24/1-GTE24/17, 2003.

Thurston, G. D. and Spengler, J. D.: A quantitative assessment of source contribution to inhalable particulate matter pollution in Metropolitan Boston, Atmos. Environ. 19, 9-25, 1985.

Trudinger, C. M., Etheridge, D. M., Sturrock, G. A., Fraser, P. J., and Krummel, P. B.: Atmospheric histories of halocarbons from analysis of Antarctic firn air: methyl bromide, methyl chloride, chloroform, and dichloromethane, J. Geophys. Res, 109(D22), D22310/1-D22310/15, 2004.
Tyler, S. C., Rice, A. L., and Ajie, H. O.: Stable isotope ratios in atmospheric $\mathrm{CH} 4$ : implications for seasonal sources and sinks, J. Geophys. Res. J. Geophys. Res., 112(D3), D03303, doi:10.1029/2006JD007231, 2007.

United Nations Environment Programme (UNEP): Handbook for the International treaties for the protection of the ozone layer, Nairobi, Kenya, Sections 1-2, 1-309, , 2003.

Watts, S. F.: The mass budgets of carbonyl sulfide, dimethyl sulfide, carbon disulfide and hydrogen sulfide, Atmos. Environ., 34, 761779, 2000.

World Meteorological Organization (WMO), Scientific assessment of ozone depletion: 2002. Global Ozone research and Monitoring Project - Report No. 47, 498 pp., Geneva, Switzerland, 2003.

Xiao, Y., Jacob, D. J., and Turquety, S.: Atmospheric acetylene and its relationship with $\mathrm{CO}$ as an indicator of air mass age, J Geophys. Res., 112, D12305, doi:10.1029/2006JD008268, 2007.

Xu, X., Bingemer, H. G., and Schmidt, U.: An empirical model for estimating the concentration of carbonyl sulfide in surface seawater from satellite measurements, Geophys. Res. Lett., 29(9), 1316, doi:10.1020/2001GL014252, 2002.

Yoshida, Y., Wang, Y., Zeng, T., Yantosca, R.: A three-dimensional global model study of atmospheric methyl chloride budget and distributions, J. Geophys. Res, 109(D24), D24309/1-D24309/15, doi:10.1029/2004JD004951, 2004. 